\title{
Macroencapsulation of Mixed Waste Debris at the Hanford Nuclear Reservation - Final Project Report by AST Environmental Services, LLC
}

Date Published

February 1998

Prepared for the U.S. Department of Energy

Fluor Daniel Hanford, Inc.

P.O. Box 1000

Richland, Washington

Hanford Management and integration Contractor for the

U.S. Department of Energy under Contract DE-AC06-96RL13200

Approved for Public Release; Further Disșemination Unlimited 


\section{RELEASE AUTHORIZATION}

Document Number: HNF-1846

Macroencapsulation of Mixed Waste Debris at the

Document Title:

Hanford Nuclear Reservation - Fial Project Report by AST Environmental Services, LLC

NOTE: Copyrighted information reprinted with permission; on file with archive copy at Central Files.

This document, reviewed in accordance with DOE Order 1430.1D, "Scientific and Technical Information Management," and DOE G 1430.1D-1, "Guide to the Management of Scientific and Technical Information," does not contain classified or sensitive unclassified information and is:

APPROVED FOR PUBLIC RELEASE
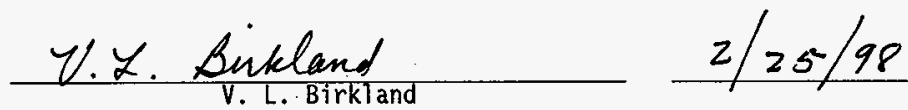

Lockheed Martin Services, Inc.

Document Control/Information Clearance

Raviewed for Applied Jechnology, Business Sensitive, Classified, Copyrighted, Export Controlled, Patent, Personal/Private, Proprietary, Protected CRADA, Trademark, Unclassitied Controlled Nuclear Information.

LEGAL DISCLAIMER. This report was prepared as an account of work sponsored by an agency of the United States Government. Neither the United States Govemment nor any agency thereof, not any of their employees, nor any of their contractors, subcontractors or their employees, makes any warranty, express or implied, or assumes any legal liability or responsibility for the accuracy,

completeness, or any third party's use or the results of such use of any information, apparatus, product, or process disclosed, or represents that its use would not infringe privately owned rights. Reference herein to any specific commercial product, process, or service by trade name, trademark, manufacturer, or otherwise, does not necessarily constitute or imply its endorsement. recommendation, or favoring by the United States Government or any agency thereof or its contractors or subcontractors. The views and opinions of authors expressed herein do not necessarily state or reflect those of the United States Government or any agency thereof. This report has been reproduced from the best available copy. Printed in the United States af America. 


\title{
PREFACE
}

\section{Macroencapsulation of Mixed Waste Debris at the Hanford Nuclear Reservation Final Project Report}

\begin{abstract}
AST Environmental Services, LLC (ASTES) was contracted by Waste Management Federal Services of Hanford, Inc. to complete a pilot macroencapsulation project during Fiscal Year 1997. The project consisted of compacting drums containing mixed waste debris, placing the compacted waste inside polyethylene tubes, and seal welding polyethylene end caps onto the tubes. The contract required that ASTES enter into a subcontract with ATG, Inc. for compaction services, and another subcontract with Arrow Construction, Inc. for macroencapsulation of the compacted drums. ASTES was also required to provide project integration, and to submit a final report after completion of the project.
\end{abstract}

The macroencapsulation project was completed in September 1997 with the compaction and macroencapsulation of 880 drums (185 cubic meters) of mixed waste debris. Total cost for this pilot project was $\$ 2.3$ million. The total contract amount for the preparation and implementation of the Project Management Plan, including the workscope defined above, was $\$ 1,534,913$.

AST Environmental Services' Final Project Report follows.

For additional copies contact:

Document Control Services

Lockheed Martin Services, Inc.

2440 Stevens Center, H6-08, P.O. Box 950

Richland, WA 99352

Voice (509) 376-1418 or (509) 372-2420

FAX (509) 376-4948

E mail: ^public_requests_hanford_docs@rl.gov

Preface prepared by:

Waste Management Federal Services of Hanford, Inc.

P.O. Box 700

Richland, WA 99352. 


\section{FINAL REPORT}

\section{Macroencapsulation of Mixed Waste Debris at the Hanford Nuclear Reservation}

October, 1997 


\section{INFORMATION CLEARANCE FORM}

\begin{tabular}{ll}
\multicolumn{2}{c}{ A. Information Category } \\
$\square$ Abstract & $\square$ Journal Article \\
$\square$ Summary & $\square$ Internet \\
$\square$ Visual Aid & $\square$ Software \\
$\square$ Full Paper & $\square$ Report \\
$\square$ Other & \\
\hline
\end{tabular}

\begin{tabular}{l} 
B. Document Number HNF-1846 \\
$\begin{array}{l}\text { C. Titie } \\
\text { MacroencapsuTation of Mixed Waste Debris at the Hanford Nuclear } \\
\text { Reservation - Final Project Report by AST Environmental } \\
\text { Services, LLC }\end{array}$ \\
\hline D. Internet Address
\end{tabular}

E. Required information

(1) Is document potentially Classitied? $\mathrm{X}$ ) No $\square$ Yos (MANDATORY) 象

Manager's Signature Required

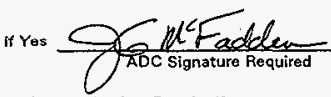

2. Internal Review Required?

if Yes, Document Signatures Below

No $\square$ Yes Classitied [x] No $\square$ Yes

Counsel

Program

3. References in the Information are Applied Technology Export Controlled Information

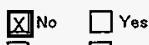

No $\square$ Yes
4. Does information Contain the Following: (MANOATORY)

a. New or Novel (Patentable) Subject Matter? $\quad \square$ No $\square$ Yes

If "Yes", Disclosure No.:

b. Information Received in Confidence, Such as Propriatary and/or Inventions?

$X$ No $\square$ Yes If "Yes", Affix Appropriate Legends/Notices.

c. Copyrights? $\square$ No $\square$ Yes If "Yes", Attach Permission.

d. Trademarks? $X$ No $\square$ Yes If "Yes", Identify in Document.

5. Is Information requiring submission to OSTI? $X$ No $\square$ Yes

If Yes UC- 2000 and $B \& R-E W 3130020$

6. Release Level? $\square$ Public $\square$ Limited

7. Charge code G3I2B

F. Complete for a Journal Article

1. Title of Journal

G. Complete for a Presentation

1. Title for Conference or Meeting

2. Group Sponsoring

3. Date of Conference

5. Will Information be Published in Proceedings? $\square$ No $\square$ Ves

4. City/State

H. Author/Requestor

Thomas L. Baker

(Print and Sign)

1. Reviewers

Reviowers Yes Ppint Williamson for

oeneral counsel FDH $[\mathrm{D}$ Ennifer T. Curtis

6. Will Material be Handed Out? $\square$ No $\square$ Yes

- Office of External Affairs

DOE-RL.

$\square$

other.

$\square$

other

Ken L. Hi adek (Print and Sign)

Public Y N (If $N$, complete J)

Signature

Bachase QUT) ilecomon

(V) $/ \mathrm{N}$

$Y / N$

$Y / N$

$Y / N$

$Y / N$

$\mathrm{J}$. If Information Includes Sensitive Information and is not to be released to the Public indicate category below.

$\square$ Applied Technology

$\square$ Personal/Private

$\square$ Protected CRADA

$\square$ Proprietary

$\square$ Business-Sensitive

$\square$ Export Controlled

$\square$ Predecisional

D Procurement-Sensitive

$\square$ Patentable

$\square$ Other (Specify)

$\square$ UCNI

K. If Additional Comments, Please Attach Separate Sheet
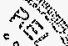



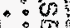




\section{APPLICATION FOR PERMISSION TO USE YOUR COPYAIGHTED MATERIAL}

To: AST Environmental Services, L.L.C 120 DId Mill Court

Fayetteville, Georgia 30214

Permission is requested to reproduce the following copyrighted material from:

FINAL REPORT titled Macorencapsulation of Mixed Waste Debris at the Hanford Nuclear Reservation", dated October 1997

Selections from text (specify by date of issue, page, paragraph, or illustration; if desised, artach a copy of the material in question):

The entire report will be reproduced and distributed.

Title of work or project in which this material will be included:

The title will be unchanged.

Estimated publication date: February 27, 1998

Author: AST Environmental Services, L.L.C

Publisher (if applicablel: Not applicable

If the copyrighted material is not to be used in a published work, please provide a brief description of how it is to be used:

Copies of report will be duplicated and distributed.

A self-addiessed stamped envelopo is enclosed for your reply.

Nams: Thomas L. Baker

MSIN: $H 6-06$

Date: February 20, 1298

Signature:

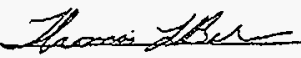

\section{Credit line (if required):}

Applleation approved by:

Name: $E, H . V E I E R$

Date: $2-23-98$

company Name: $5 \sqrt{E}$ ENVLRONGENTFe SUS LCC

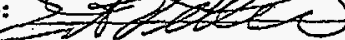

signatory's Position: QEN.MGR (on behalf of) 
Demonstration and Evaluation of Arrow Construction's.ARROW-PAK For The Macroencapsulation and as an Improved Container For Mixed Waste Debris Treatment, Storage and Disposal Performed At The Department of Energy Hanford Site Richland, Washington

Date Issued: October 24, 1997

Prepared by

AST Environmental Services, L.L.C.

120 Old Mill Court

Fayetteville, Georgia 30214

Prepared for

Waste Management Federal Services of Hanford, Inc.

P.O. Box 700

Richland, Washington 99352 


\section{Table Of Contents}

1. INTRODUCTION ......................................................................................................................................1-1

2. DESCRIPTION AND PURPOSE OF PILOT DEMONSTRATION PROJECT .......................................2-3

2.1 PROJECT SCOPE AND PURPOSE...........................................................................................................

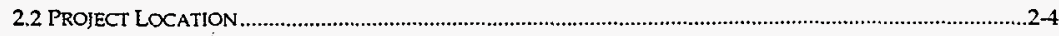

2.3 WASTE FEED STOCK …….................................................................................................................

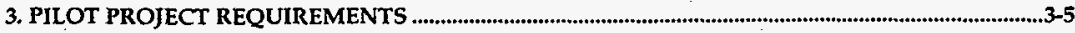

3.1 REGULATORY AND PROCEDURAL REQUIREMENTS .............................................................................5

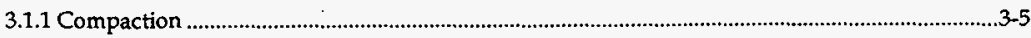

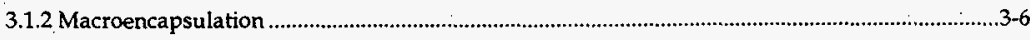

3.2 ADMINISTRATIVE REQUIREMENTS ..........................................................................................

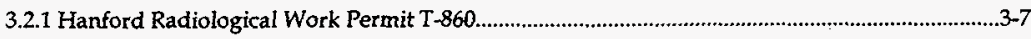

3.2.2 Hanford Job Hazard Analysis ....................................................................................................3-8

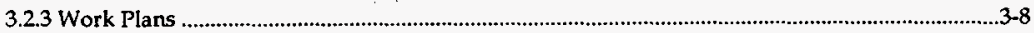

3.2.4 Quality Assurance/Quality Control ......................................................................................9-9

3.2.5 Project Coordination Requirements ................................................................................3-10

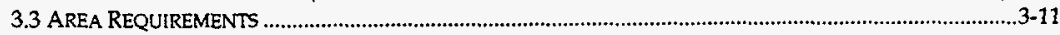

3.4 EQUIPMENT REQUIREMENTS .............................................................................................

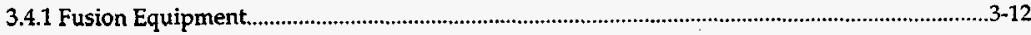

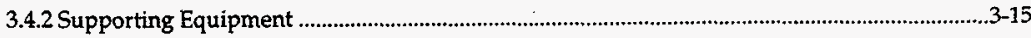

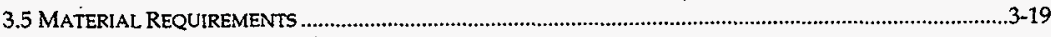

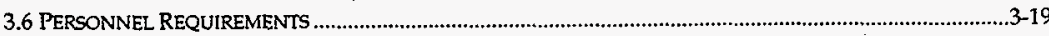

3.6.1 Key Personnel ......................................................................................................................

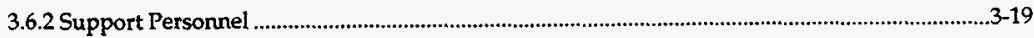

3.7 WASTE MANAGEMENT REQUIREMENTS....................................................................................2-20

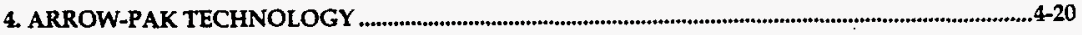

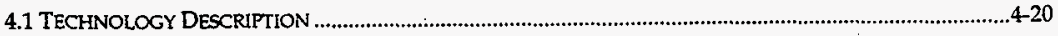

4.2 ARROW-PAK ENGINEERING SPECIFICATIONS............................................................................4-21

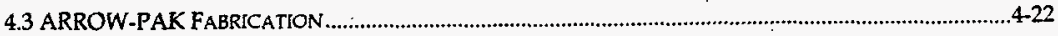

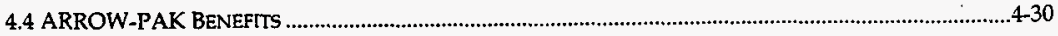

5. PERFORMANCE DATA

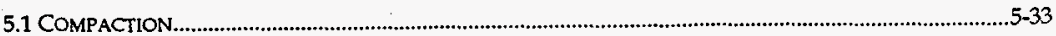

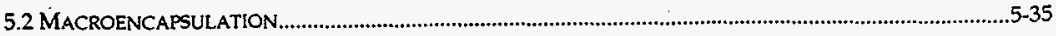

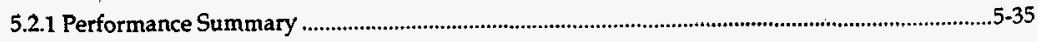


5.2.3 Macroencapsulation Operations............................................................................................... $5-37$

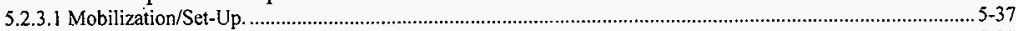

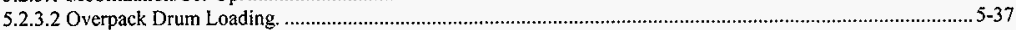

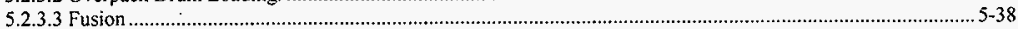

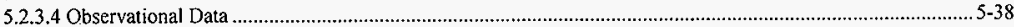

6. COST DATA

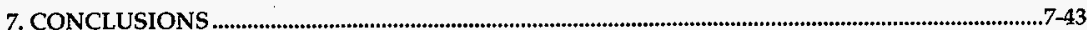

8. POTENTIAL FOR FULL-SCALE PRODUCTION USE OF ARROW-PAK ..............................................8-44

\section{LIST OF TABLES}

TABLE 4-1. ARROW-PAK ENGINEERING SPECIFICATIONS FOR STANDARD 28-INCH INCH UNITS ..................4-22 TABLE 5.1.1 GENERAL CONTAINER AND COMPACTION PROCESS WASTE GENERATION INFORMATION ........5-34 TABLE 5.1.2 ATG RICHLAND.MIXED WASTE DEBRIS COMPACTION PERFORMANCE DATA.............................5-34

\section{LIST OF FIGURES}

FIGURE 3-1 ARROW-PAK STORAGE AREA .............................................................................................12

' FIGURE 3-2 FUSION MACHINE ............................................................................................................3-13

FIGURE 3-3 HEATER SURFACE TEMPERATURE CHECK..............................................................................

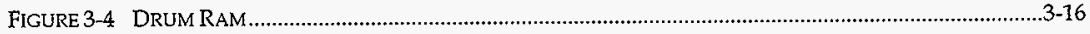

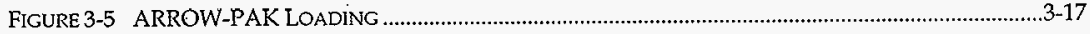

FIGURE 3-6 ARROW-PAK LOADING RACK

FIGURE 4-1 ARROW-PAK SUPPORT SYSTEM...............................................................................................25

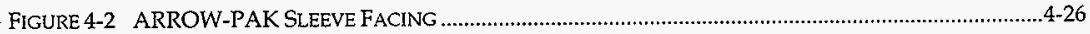

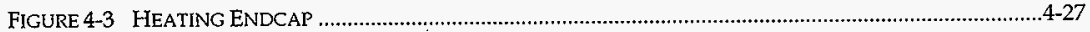

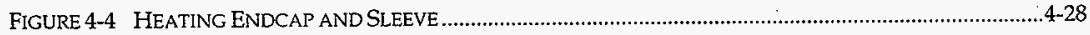

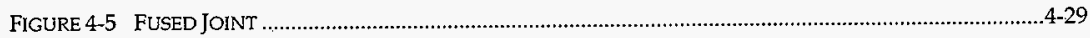

\section{ATtaChMENTS}

1 Radiological Work Permit No. T-860

2 Waste Management of Hanford Inc. Letter of Approval 


\section{ABSTRACT}

This report summarizes the results of a full-scale demonstration of a high density polyethylene (HDPE) package, manufactured by Arrow Construction, Inc. of Montgomery, Alabama. The HDPE package, called ARROW-PAK, was designed and patented by Arrow as both a method for to macroencapsulation of radioactively contaminated lead and as an improved form of waste package for treatment and interim and final storage and/or disposal of drums of mixed waste. Mixed waste is waste that is radioactive, and meets the criteria established by the United States Environmental Protection Agency (US EPA) for a hazardous material. Results from previous testing conducted for the Department of Energy (DOE) at the Idaho National Engineering Laboratory in 1994 found that the ARROWPAK fabrication process produces an HDPE package that passes all helium leak tests and drop tests, and is fabricated with materials impervious to the types of environmental factors encountered during the lifetime of the ARROW-PAK, estimated to be from 100 to 300 years. Arrow Construction, Inc. has successfully completed full-scale demonstration of its ARROW-PAK mixed waste macroencapsulation treatment unit at the DOE Hanford Site. This testing was conducted in accordance with Radiological Work Permit No. T-860, applicable project plans and procedures, and in close consultation with Waste Management Federal Services of Hanford, Inc.'s project management, health and safety, and quality assurance representatives. The ARROW-PAK field demonstration successfully treated 880 drums of mixed waste debris feedstock which were compacted and placed in 149 70-gallon overpack drums prior to macroencapsulation in accordance with the US EPA Alternate Debris Treatment Standards, 40 CFR 268.45. Based on all of the results, the ARROW-PAK process provides an effective treatment, storage and/or disposal option that compares favorably with current mixed waste management practices. 


\section{INTRODUCTION}

The purpose of this project was to demonstrate the ARROW-PAK macroencapsulation technology to meet 40 CFR Part 268.45. The objective of this macroencapsulation project was to conduct an appropriate demonstration of the ability of a container to safely and efficiently encapsulate mixed waste debris in order to isolate the contents of the container from the environment. The reason for this activity was to establish and perform macroencapsulation of mixed waste debris to meet US EPA treatment and disposal requirements. The demonstration successfully met all project requirements and objectives.

DOE's objective was to make technology available to all DOE sites, and expected the following benefits as a result of this successful initiative:

- The process is, by design, highly portable. It is hoped that this technology and the associated treatment process will be used by other hazardous/mixed debris treatment facilities.

- Allows for the treatment and disposal of mixed or hazardous waste debris in lieu of a prolonged storage cycle.

- Is projected to be cost effective as a treatment option and reduces the need for additional expensive indoor long-term storage capability.

- Environmental contamination concerns are minimized through the application of this process.

- Once the process is demonstrated, it may be used by generators with access to disposal in a lined land-fill, or an indoor/outdoor storage area.

This demonstration project was jointly funded by the DOE Office of Waste Management (EM30 ) and the Office of Science and Technology (EM-50). The Richland Operations Office of the United States Department of Energy (DOE-RI) and their Prime Contractors began the project in 1996. The original contractor was Westinghouse Hanford Company (WHC). Fluor Daniel Hanford, Inc. succeeded WHC as the Management and Integration (M\&I) contractor in October, 1996. Waste Management Federal Services of Hanford, Inc. (formerly Rust Federal Services of Hanford Inc.) is a major subcontractor responsible for Solid Waste Management at Hanford, and managed this demonstration Project.

AST Environmental Services, LLC was contracted by Westinghouse Hanford Company in September, 1996 to provide Project Management Services for the macroencapsulation of mixed waste debris. Previously, a Macroencapsulation Program Plan had been developed which determined the necessary project requirements and evaluated 9 macroencapsulation technology vendors. The qualification criteria that were used to establish the parameters of the project were divided into four areas. These were: 
1. Technical Soundness

2. Future Implementation

3. Fair and Reasonable Cost

4. Achievement of Programmatic Goals

To ensure a successful demonstration, additional criteria were used to evaluate the macroencapsulation technologies. One criteria was prior testing, or data generated from independent testing performed at a DOE facility, in particular, testing for the macroencapsulation of mixed waste debris. An additional criteria was that the macroencapsulation media not be sealed by mechanical means, i.e., that it be a completely monolithic or welded container. The ARROW-PAK was selected as the macroencapsulation technology meeting all of the technical and programmatic requirements, as well as having passed all of the DOE independent testing.

The patented ARROW-PAK Macroencapsulation treatment units used on this project were constructed of 30 inch outer diameter, 0.923 inch wall thickness, high density polyethylene (HDPE) pipe with 1.375 inch thick HDPE caps welded to the ends. The HDPE pipe is specially designed to withstand physical and environmental stresses expected to be encountered during mixed waste debris treatment, storage and disposal operations. The resin used in the manufacture of the ARROW-PAK sleeves and end caps was previously tested by the DOE, and shown to be resistant to leaks and ultraviolet (UV) degradation, with an outdoor storage life expectancy of between 100 and 300 years.

Prior to beginning field macroencapsulation operations, it was necessary to demonstrate compliance with all regulatory criteria of the State of Washington Department of Ecology (Ecology) for the treatment and disposal of hazardous (mixed) waste debris. Additionally, compliance with all DOE-RL site specific requirements regarding Health and Safety, Operating Procedures, Quality Assurance/Quality Control, and Employee Training had to be achieved. The project received approval from Ecology, DOE-RL, and the site contractor(s), and successfully met all technical, operational and regulatory requiremients.

EPA regulation 40 CFR 265.315 requires that containers (drums) be at least $90 \%$ full prior to placement in a landfill. Drums not meeting this criteria are required to be crushed, shredded, or similarly reduced in volume to the maximum practical extent before burial. Compaction of the drums to remove these voids is the preferred option. The drums that were macroencapsulated during this demonstration project were compacted at the Allied Technology Group, Inc. facility in Richland, Washington and placed into overpacks as a result of a treatability study conducted by Waste Management Federal Services of Hanford, Inc.

Allied Technology Group, Inc. successfully compacted 880,55 -gallon drums that were stored in facilities at the Hanford site and delivered 149 overpack drums containing the 880 compacted drum pucks to Waste Management Federal Services of Hanford, Inc. for macroencapsulation operations at the T-Plant complex in the 200 area of the Hanford Nuclear Reservation. Waste Management Federal Services of Hanford, Inc. T-Plant personnel and Arrow Construction. Inc. completed macroencapsulation treatment according to the US EPA debris rule utilizing the patented ARROW-PAK Macroencapsulation treatment, storage and disposal technology. Each ARROW-PAK Macroencapsulation Treatment Unit was designed to treat up to 7 of the overpack drums received from Allied Technology Group, Inc. (ATG). A total of 21 full length ARROW. PAK Macroencapsulation Treatment Units were processed during the course of this full-scale 
production demonstration project. Additionally, 1 ARROW-PAK was shortened in the field to treat 2 Allied Technology Group (ATG) overpacks.

\section{DESCRIPTION AND PURPOSE OF PILOT DEMONSTRATION PROJECT}

\subsection{Project Scope and Purpose}

The purpose of this program was to perform macroencapsulation of mixed waste debris according to the US EPA debris rule in 40 CFR 268.45. The Hanford Site pursued and implemented a production scale demonstration with available technology that was also acceptable to the regulatory authorities governing activities at Hanford. In pursuing this approach, the Hanford site worked out many of the logistics associated with bringing a bench or pilot scale operation to a production scale project.

The majority of the mixed waste debris in storage and forecasted to be stored/disposed at Hanford could be treated by macroencapsulation. The total amount of mixed waste debris expected to be generated at Hanford is estimated to be 36,000 cubic meters over the next 20 years of clean up effort according to the "Final Waste Management Programmatic Environmental Impact Statement" published in May 1997 by DOE-HQ.

Other sites within the DOE complex are considering using macroencapsulation to treat their debris waste. The performance and cost data will be shared with other Federal Agencies in need of mixed waste debris treatment. By sharing technical performance and cost data with Federal Interagency Offices, the DOE can exhibit expenditure avoidance with multiple branches of the Federal Government while providing generators of debris mixed waste with field-ready and fieldtested solutions.

The problem addressed by this program is that there is little capacity within the United States to treat Resource Conservation and Recovery Act (RCRA) mixed waste. This has caused the DOE to develop the capacity to store all of their mixed waste in RCRA compliant storage facilities. The capacity at Hanford and throughout the rest of the DOE complex is approaching the administrative control capacity.

Other DOE sites have indicated interest with the application of the debris rule, specifically macroencapsulation, to their own waste, and have proposed several different approaches and pilot scale projects. Hanford applied these pilot scale operations to actual waste streams by implementing a cost effective and technically qualified technology. Application of the technology facilitated the final step in macroencapsulation treatment, performing the operations that have been successfully demonstrated by DOE and Arrow Construction on surrogate waste. This project worked out the technical issues associated with both the process and the regulatory agencies involved.

Now that the process has been successfully demonstrated, it is available for use by generators with a need for mixed waste debris treatment capability. This treatment may result in final disposal in a permitted landfill, or provide a superior container for long term on-site outdoor storage without the need for additional storage facilities. 


\subsection{Project Location}

The macroencapsulation was performed at the Hanford T-Plant facility's mixed waste treatment pad. T-Plant is located in the Hanford 200 West area. The compacted 55-gallon drum "pucks" were repackaged into modified 70-gallon overpack drums at ATG, and transported back to Hanford's T-Plant facility. The modified 70-gallon overpack drums were then macroencapsulated in the ARROW-PAK Macroencapsulation Treatment Units. The ARROWPAK Macroencapsulation Treatment Units are being stored at the Hanford T-Plant facility until they can be transferred to the Hanford mixed waste disposal trenches in the 200 West area, at the Hanford Central Waste Complex.

\subsection{Waste Feed Stock}

The feed stock for the ATG treatability study consisted of 163,85-gallon and 717, 55-gallon drums of mixed waste debris ( 880 drums total). The 85 -gallon drums contained 55 -gallon drums that did not meet the Hanford mixed waste storage double containment requirements or were determined by Hanford staff to be lacking in structural integrity. The 55-gallon drums inside the 85-gallon drums were removed and processed through the ATG compactor as a part of the treatability study. The absorbent material inside the 85 -gallon drums was used as needed in the modified 70-gallon overpacks that the compacted 55-gallon drums were placed into. These modified 70-gallon drums containing the compacted 55-gallon drum "pucks" were used as the waste feed stock for the ARROW-PAK Macroencapsulation Treatment Units. The empty 85gallon drums were returned to Hanford as RCRA empty drums for re-use.

The 880 drums compacted under the ATG treatability study contained or possessed the following:

- a total of 0.761 curies of the following isotopes:

Am-241 Co-60 Cs-137 Eu-154 Pu-238 Pu-239 Pu-240 Pu-241

$\mathrm{Pu}-242 \quad \mathrm{Sr}-90$

- The Following waste codes:

F001-F005, D007-D008, WC02, WP02, WT01, WT02

Where F001-F005 are spent halogenated and non-halogenated solvent waste codes

D007 represents the waste code for chromium

D008 represents the waste code for lead

WC02 represents the Washington State code for carcinogenic substances

WP02 represents the Washington State code for persistent dangerous halogenated hydrocarbon waste 
WT01 and WT02 represent Washington State codes for toxic dangerous and extremely hazardous toxic waste, respectively

- The following is a list of chemicals contained in the 880 drums processed that resulted in the above waste codes:

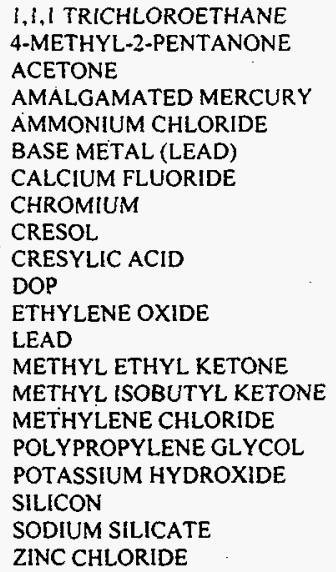

\section{PILOT PROJECT REQUIREMENTS}

\subsection{Regulatory and Procedural Requirements}

\subsubsection{Compaction}

US EPA regulation 40 CFR 265.315 requires that containers (drums) be at least $90 \%$ full prior to placement in a landfill. The majority of the drums to be macroencapsulated at Hanford do not meet this requirement, and US EPA regulations require that the containers be crushed, shredded, or similarly reduced in volume to the maximum practical extent before burial.

The Washington State Department of Ecology (Ecology) is the regulatory agency in Washington State that is responsible for the implementation and enforcement of Federal and State environmental laws and regulations. Ecology considers compaction of mixed waste as treatment and therefore requires that facilities engaged in such activity possess a RCRA part A or B permit to process such waste. Allied Technology Group was issued a US EPA processing number to perform a compaction treatability study in compliance with State/Federal exemptions. The drums compacted by ATG under that treatability study were used for the ARROW-PAK macroencapsulation demonstration. 


\subsubsection{Macroencapsulation}

The Land Disposal Restriction regulations for debris, promulgated on August 18. 1992 (57 CFR 371.94) begin with the following definitions of "debris" and "hazardous debris:"

"Debris means solid material exceeding a $60 \mathrm{~mm}$ particle size that is intended for disposal and that is: A manufactured object; or plant or animal matter; or natural geologic material. However the following materials are not debris: Any material for which a specific treatment standard is provided in Subpart D of 40 CFR 268, namely lead acid batteries, cadmium batteries, and radioactive lead solids; process residuals such as smelter slag and residues from the treatment of waste, wastewater, sludges, or air emission residues; and intact containers of hazardous waste that are not ruptured and that retain at least $75 \%$ of their original volume. A mixture of debris that has not been treated to the standard provided by 40 CFR 268.45 and other material is subject to regulation as debris if the mixture is comprised primarily of debris, by volume, based on visual inspection."

"Hazardous debris means debris that contains a hazardous waste listed in subpart D of 40 CFR 261 , or that exhibits a characteristic of hazardous waste identified in subpart C of 40 CFR 261."

Mixtures of debris and other materials, such as soils, sludges. lead acid or cadmium batteries, or radioactive lead used as shielding are considered to be debris as long as materials meeting the above definitions of debris make up more than $50 \%$ of the waste volume. The determination as to whether or not a waste matrix is primarily debris is reached by a visual inspection of the matrix. In the case of the debris processed at Hanford under this project, a visual inspection was performed by utilizing real time radiography (video $x$-ray) images.

There are three general categories that the US EPA approved for debris performance base treatment:

- Extraction Technologies

- Destruction Technologies

- Immobilization Technologies

Macroencapsulation is one of the immobilization technologies listed in the debris rule and is defined by the following:

"Application of surface-coating materials, such as polymeric organics (e.g. resins and plastics). or use of a jacket of inert inorganic materials to substantially reduce surface exposure to potential leaching media." In addition, macroencapsulation, as applied under the debris rule. contains no restrictions as to what hazardous constituents can be treated as long as the macroencapsulation media is chemically resistant to the hazardous constituent.

The Washington State Department of Ecology adopted the US EPA debris rule by reference in the Washington Administrative Code 173-303 as amended in November, 1995. The Washington Administrative Code 173-303 is the Washington State law governing hazardous waste treatment, storage and disposal in the State of Washington and is the documentation used by the State of Washington to assume the EPA's responsibilities for protection of human health and the environment. 
One of the requirements that the US EPA has on states that assume the responsibility of protecting human health and the environment within the state's borders is that the state's adopted environmental regulations be at least as restrictive as the federal regulations. This requirement does not prohibit states from making environmental regulations more restrictive than the federal regulations. In the case of Washington.State, there is one additional regulation that has been imposed on organizations wishing to utilize the US EPA debris rule. WAC 173-303-140 contains the Washington State land disposal restrictions. The purpose of this section is to encourage the best management practices for dangerous wastes according to the following priorities in the order listed:

1. Reduction

2. Recycling

3. Physical, chemical, and biological treatment

4. Incineration

5. Stabilization and solidification

6. Landfill

Mixed waste debris is comprised of waste items such as paper, plastic, rubber, wood, concrete and other general rubble. Much of the waste in a debris waste stream contains carbon based organic materials. The Washington State land disposal restrictions define organic / carbonaceous waste as a dangerous waste that contains combined concentrations of greater than ten percent organic/carbonaceous constituents in the waste. Organic / carbonaceous constituents are those substances that contain carbon-hydrogen, carbon-halogen, or carbon-carbon chemical bonding. WAC 173-303-140 continues to say that a person is encouraged to reclaim, recycle, recover, treat, detoxify, or otherwise process organic/carbonaceous wastes and that as a minimum management method, organic / carbonaceous waste must be incinerated.

The waste processed during this macroencapsulation project was determined by Ecology to meet the organic/carbonaceous definition in WAC 173-303-140. Because of a national lack of capacity of facilities with appropriate permits and capabilities for incinerating mixed waste debris, a waiver was issued to the organic/carbonaceous rule by Ecology prior to commencement of macroencapsulation operations at Hanford.

\subsection{Administrative Requirements}

As discussed earlier in this report, the ARROW-PAK Macroencapsulation Treatment Demonstration at the DOE Hanford Site was a joint effort between DOE, Waste Management Federal Services of Hanford, Inc., ASTES and Arrow Construction, Inc. designed to test and document the patented technology's ability to treat mixed waste feedstock under actual field conditions. This section briefly summarizes the most important requirements for safe and successful execution of this project.

\subsubsection{Hanford Radiological Work Permit T-860}

The controlling requirement for the conduct of macroencapsulation field operations was Hanford Radiological Work Permit (RWP) Number T-860 prepared by Waste Management Federal 
Services of Hanford, Inc., a copy of which is enclosed as Attachment 1. This permit outlined the radiological conditions, contamination levels, minimum protective requirements, and special instructions associated with all phases of the Treatment Demonstration. The requirements of RWP T-860 were applicable to all workers on the site. including any visitors.

All participants in the Macroencapsulation Treatment Demonstration participated in a formal review of RWP T-860 at the Pre-Construction Meeting (initial Pre-Job Meeting) on 2 September. 1997. Each member of the Macroencapsulation Demonstration team retained a copy of RWP $T$ 860 for reference throughout the demonstration.

\subsubsection{Hanford Job Hazard Analysis}

The Hanford Job Hazard Analysis (JHA) was prepared by Waste Management Federal Services of Hanford, Inc.'s Safety Representative based on RWP T-860, Arrow Construction's SiteSpecific Health and Safety Plan, and interviews with members of the Arrow Demonstration Team prior to conduct of field operations. The JHA identifies the known or potential hazards and the required control (hazard elimination) measures associated with the project. The Safety Representative discussed the requirements of the JHA with all participants in the Treatment Demonstration, as appropriate, during the daily Pre-Job Meetings. The Safety Representative prepared the Construction/Project Safety Surveillance Report, dated 5 September. 1997, which concluded that all aspects of the Macroencapsulation Treatment Demonstration (including planning, training, and execution) were satisfactory and that the field operations were conducted safely and in accordance with the Site-Specific Health and Safety Plan and the Job. Hazard Analysis.

\subsubsection{Work Plans}

The general support requirements of the Demonstration's vendor, Arrow Construction. are outlined in the Work Plan for the Debris Macroencapsulation Pilot Project, DOE Hanford Site, August, 1997, as amended (hereinafter referred to as Work Plan). This plan represents the operational basis of all activity conducted by the Macroencapsulation Demonstration team, including health and safety support. While it does not direct the activities of Waste Management Federal Services of Hanford, Inc., the Work Plan identifies the support required from others (i.e., waste debris compaction, crane and rigging support, and health physics) and it serves as a reference for the coordination of this external support. As appropriate, the Work Plan was modified by Waste Management Federal Services of Hanford, Inc.'s approved field changes.

Appendix B of the Work Plan contained the project's Site-Specific Health and Safety Plan which was reviewed and approved by Waste Management Federal Services of Hanford. Inc.'s Safety Representative prior to the start of field operations. In addition to the Job Hazard Analysis and the oversight provided by the Safety Representative, the Health and Safery Plan was the reference for all of the Health and Safety Officer's activities.

The Contingency Plan for the Debris Macroencapsulation Pilot Project, DOE Hanford Site, November, 1996 (Contingency Plan) was prepared by Arrow Construction. Inc. to meet contingency planning and emergency preparedness requirements outlined in WAC 173-303.350 and -360 . The intent of this plan is to ensure that measures are in place to reduce the potential 
impact on public/employee health and the environment in the event of a facility emergency involving stored mixed waste or petroleum products. The Contingency Plan was based on (and was used in conjunction with) the T-Plant Building Emergency Plan (WHC-IP-0263-TPC) and the Sitewide Contingency Plan (WHC-EP-0564).

\subsubsection{Quality Assurance/Quality Control}

Arrow Construction's Quality Assurance Program Plan for the Debris Macroencapsulation Pilot Project, DOE Hanford Site, dated November, 1996 and modified August, 1997 (QAPP) established the means of implementing and maintaining a Quality Assurance Program (QAP) commensurate with the risk and complexity for the overall operation of the Macroencapsulation Treatment Demonstration. The QAPP identified the requirements and methods to be used by the Demonstration Team to implement the QAP, and applied to procurement, installation, operation, and maintenance activities associated with Arrow Construction's scope of work on the Macroencapsulation Treatment Demonstration. The QAP did not apply to project activities conducted by others.

The QAPP included, but was not limited to, the following annotated topics:

QA Program. Of the three QA Program criteria identified in the QAPP, only Quality Category 2 (On-Site Safety) applies to the Macroencapsulation Treatment Demonstration. This criterion encompasses those items for which failure could impact the health and safety of on-site personnel through radiological hazards, environmental contamination, or significant physical hazards. Category 2 items have a level of concern of "medium".

Also critical to the QA Program for this project is the accepted industry standard for HDPE fusion. The ASTM Designation D2657-90, Standard Practice for Heat Joining Polyolefin Pipe and Fittings was the standard used for all heat fusion welds during the demonstration.

- Training. The training program was designed to comply with applicable US EPA, OSHA, state regulations, DOE Orders, and Hanford policies and procedures. All Arrow Construction field personnel received (or were previously certified for) the following training:

- OSHA 40-Hour HAZWOPPER per 29 CFR 1910.120;

- Radiological Worker II Training, as specified in the Hanford Radiological Controls Manual (RWP T-860 specified Radiological Worker I Training);

- General Employee Training, as specified in the Hanford Radiological Controls Manual;

- T-Plant Facility-Specific Training, as specified in the Hanford Radiological Controls Manual, and;

- Arrow Construction's internal operations and health and safety training.

Quality Improvements. The Project Director, with the assistance of the Quality Assurance Officer and Waste Management Federal Services of Hanford, Inc.'s Quality Representative. was responsible for ensuring that conditions not conforming to quality standards identified in the 
QAPP were identified, reported, and corrected to enhance performance and minimize variability. However, all field personnel were granted the authority to stop any work until effective corrective action was completed should non-conforming conditions exist. In recognition that this project is a first-of-its-kind mixed waste treatment demonstration, all Demonstration Team members realized the importance of executing any appropriate quality improvements during the project that transcended mere adherence with the QAPP or the other Work Plans.

Record Keeping. Documentation procedures on this project fulfilled the requirements of DOE Order 1324.5B and 40 CFR 264 and 265.

Work Processes/Calibration. Section 5.5 of the QAPP addressed the requirements for work processes, including the calibration of monitoring and data collection equipment.

As specified in this section, all measurement and testing equipment used to determine conformance to specified requirements was controlled and calibrated in accordance with the manufacturer's specifications, as applicable. For the Macroencapsulation Treatment Demonstration, this calibrated equipment included the interfacial pressure gauge on the ARROW-PAK Fusion Unit and the thermocouple pyrometer used to measure the temperature of the heater plate.

Inspection and Acceptance Testing. The QAPP required that the fusion welds on the ARROWPAK units be visually inspected against an approved procedure that is documented in the "Fusion Checklist" to ensure that a satisfactory seal was achieved on each unit. According to the modified QAPP, the Fusion Checklist was completed by the Project Quality Assurance Officer with oversight by Waste Management Federal Services of Hanford, Inc.'s Quality Representative for all fusion welds conducted during the Macroencapsulation Treatment Demonstration at Hanford. For those fusion welds conducted in New Orleans in December, 1996 (to cap one end of the empty ARROW-PAK units), the original QAPP was in effect. This earlier version of the procedure was identical to that described above except that no oversight by Waste Management Federal Services of Hanford, Inc.was required.

\subsubsection{Project Coordination Requirements}

Coordination was essential to the planning and preparation of the Macroencapsulation Treatment Demonstration, and it was critical to its successful execution. The organizations party to the coordination effort included DOE-Richland Operations, Washington State Department of Ecology, Waste Management Federal Services of Hanford, Inc., T-Plant Operations, AST Environmental Services (ASTES), and Arrow Construction, Inc. Once the Treatment Demonstration was underway, Arrow Construction coordinated principally with Waste Management Federal Services of Hanford, Inc//T-Plant Operations through ASTES, for the following support:

- Health Physics Technician Support

- Transportation of Waste Feedstock to Mixed Waste Treatment Pad

- Crane and Rigging Support (including waste loading of the empty ARROW-PAKs)

- Health and Safety Oversight 
- Quality Oversight

- Other Logistical/Administrative Support (including dining facility and lavatories)

- Mobilization/Demobilization Support

Coordination was streamlined to the extent possible, and was effected through daily Pre-Job Meetings and onsite consultation with various responsible parties, as appropriate. Since Arrow Construction's macroencapsulation is simple and straightforward, and since the project planning and preparations had been detailed and successful, the degree of required coordination was limited to daily safety/hazard avoidance, quality control documentation, and coordination of operations between Arrow Construction's forces and Waste Management Federal Services of Hanford, Inc.'s supporting elements.

\subsection{Area Requirements}

The ARROW-PAK Mixed Waste Treatment Demonstration was conducted on the Mixed Waste Treatment Pad at the Hanford Site's T-Plant Facility (this area is sometimes referred to as the Laydown Pad/T-Plant Parking Lot). The Mixed Waste Treatment Pad is located immediately west of Building 221-T, just inside T-Plant's fenced boundary, and encompasses most of TPlant's Designated (Emergency) Staging Area. T-Plant is located within a designated Radiologically Controlled Area (RCA). Pursuant to early coordination with Waste Management Federal Services of Hanford, Inc.(i.e., prior to deployment), the Work Plan specified a total macroencapsulation operations area and support zone of approximately 8,100 square feet.

Waste Management Federal Services of Hanford, Inc.enlarged the entire macroencapsulation operations area/support zone, referred to as a Radiological Buffer Area/Radiological Material Area (RBA/RMA), to approximately 29,000 square feet upon deployment. This afforded substantial maneuvering room for all equipment and separation distance between discrete macroencapsulation activities within the RBA/RMA. The approximate area requirements (in square feet) for those activities are as follows:

Empty ARROW-PAK Storage Area

RMA (hydraulic crane + pre-encapsulated mixed waste storage) .

ARROW-PAK Loading Area

Fusion Area

ARROW-PAK Macroencapsulation Treatment Unit Storage Area
5000 sf

$1920 \mathrm{sf}$

$420 \mathrm{sf}$

$1050 \mathrm{sf}$

$4850 \mathrm{sf}$

Once waste-loaded and fused, the ARROW-PAK Macroencapsulation Treatment Units were placed on steel chocks, or racks, in clusters of five, with a 10 -foot separation between clusters (see Figure 3-1). 


\section{THIS PAGE INTENTIONALLY LEFT BLANK}




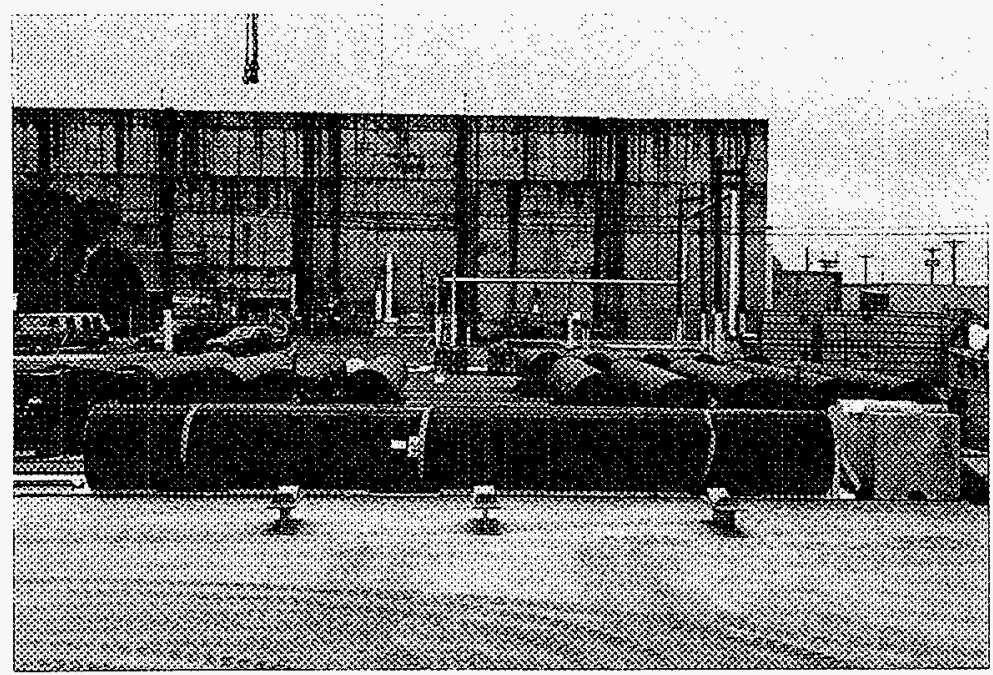

\section{FIGURE 3-1 ARROW-PAK Storage Area}

\subsection{Equipment Requirements}

The equipment requirements of the project were limited and are summarized below.

\subsubsection{Fusion Equipment}

Fusion Equipment. Fusion of the ARROW-PAK Treatment Units (as described in Section 4.1) was accomplished by the use of Arrow Construction's MEGAMC 36-inch hydraulic fusion machine which provides semi-automatic control of fusion joints (see Figure 3-2). This fusion unit features a certified calibrated Ashcroft Interfacial Pressure Gauge that enables the Fusion Specialist to read the required variable pressures for facing, heating, and fusing.

Power Supply, Electrical power for the ARROW-PAK Fusion Unit was provided by a 40-kW, 3phase, $60 \mathrm{~Hz}, 240$-volt diesel generator.

Pyrometer. Proper heater surface temperature was checked by the use of an analog thermocouple pyrometer which was calibrated and certified (see Figure 3-3). As an extra measure of quality assurance, Arrow Construction had on-hand a calibrator for its two back-up thermocouple pyrometers which were used to randomly validate the primary pyrometer reading at four locations on both sides of the heater plate. 


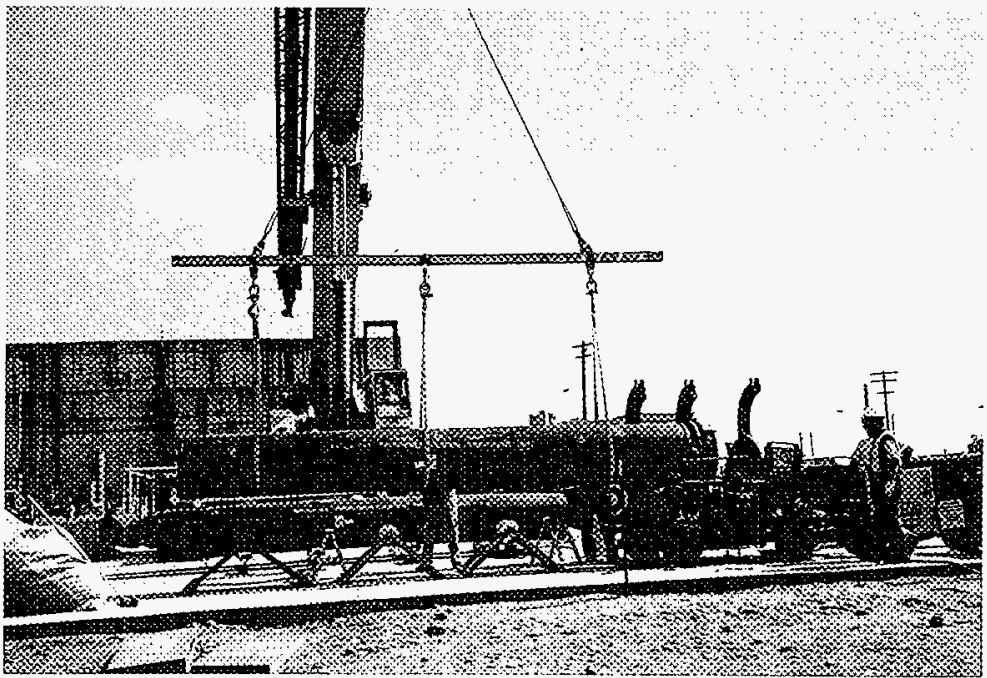

FIGURE 3-2 Fusion Machine 


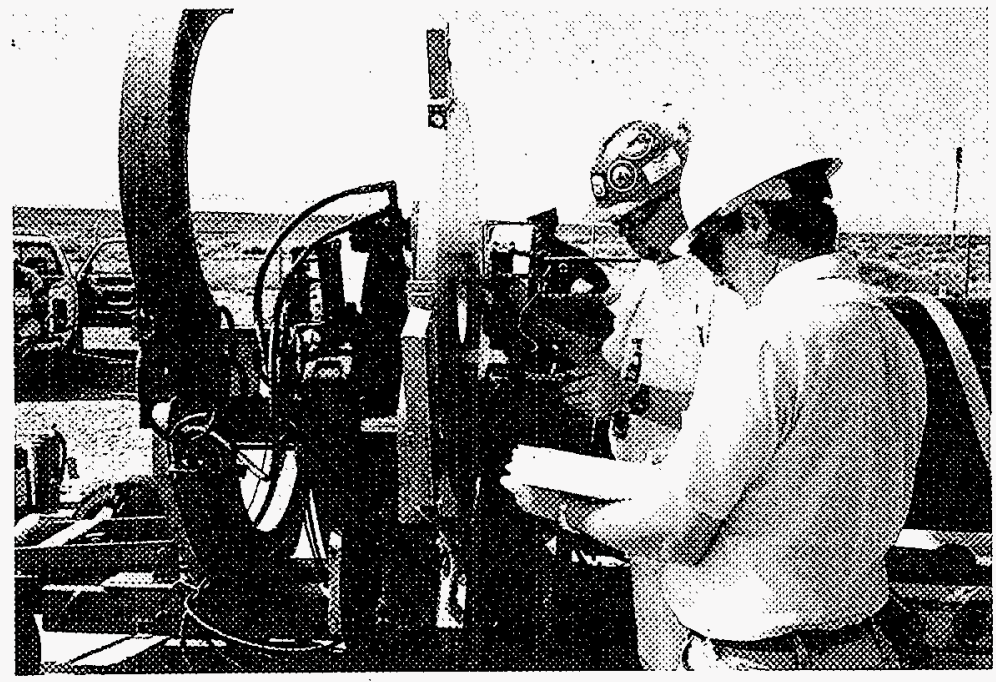

FIGURE 3-3 Heater Surface Temperature Check 


\subsubsection{Supporting Equipment}

The Work Plan called for a mobile crane and a forklift outfitted with a detachable ram assembly used to load the 70-gallon steel overpack drums (containing approximately 6 compacted 55galion drums each) into the empty ARROW-PAKs. Waste Management Federal Services of Hanford, Inc. provided the following operations support equipment upon deployment of Arrow Construction's macroencapsulation equipment to the T-Plant worksite:

Hydraulic Crane. ARROW-PAK lift capability (empty, loaded. and fused/treated units) was provided by a Grove AT Model 1100 crane with a.maximum lift capacity of 110 tons, a 130 -foot main boom, and, on this project, a swing radius of 22 to 65 feet. The crane was stationary at all times and located in the Radiological Material Area. It was used to lift and transport wasteloaded ARROW-PAK units, open and fused/treated. throughout the southwestem portion of the Radiological Buffer Area (RBA).

Forklift. This equipment was used to transport empty ARROW-PAK units from the storage area in the northern portion of the RBA to the loading rack located immediately in front (north) of the loading rack. This equipment was not used to move any waste-loaded ARROW-PAKs.

Forklift with Carpet Ram. The use of this equipment was restricted to small lifting/transport tasks and loading of empty ARROW-PAK units with seven modified 70-gallon steel overpack drums (see Figures 3-4 and 3-5). The equipment was used in place of the forklift and loading assembly proposed in the original Work Plan, because the manufacturer certified the use of the carpet ram as safe (low-risk) against damage.

Additional equipment needed for this project was furnished (and custom-made) by Arrow Construction, including a 21-foot, 9-inch aluminum ARROW-PAK waste-loading rack (see Figure 3-6) and over one hundred 80- $1 \mathrm{~b}$. welded steel chocks used to support the fused/treated ARROW-PAKs which ranged in weight from 5,600 to 7,700 pounds. The loading rack was lightweight, yet strong, and easily assembled and disassembled given its modular construction: Five chocks were needed to support every ARROW-PAK Macroencapsulation Treatment Unit (i.e., loaded and fused unit). 


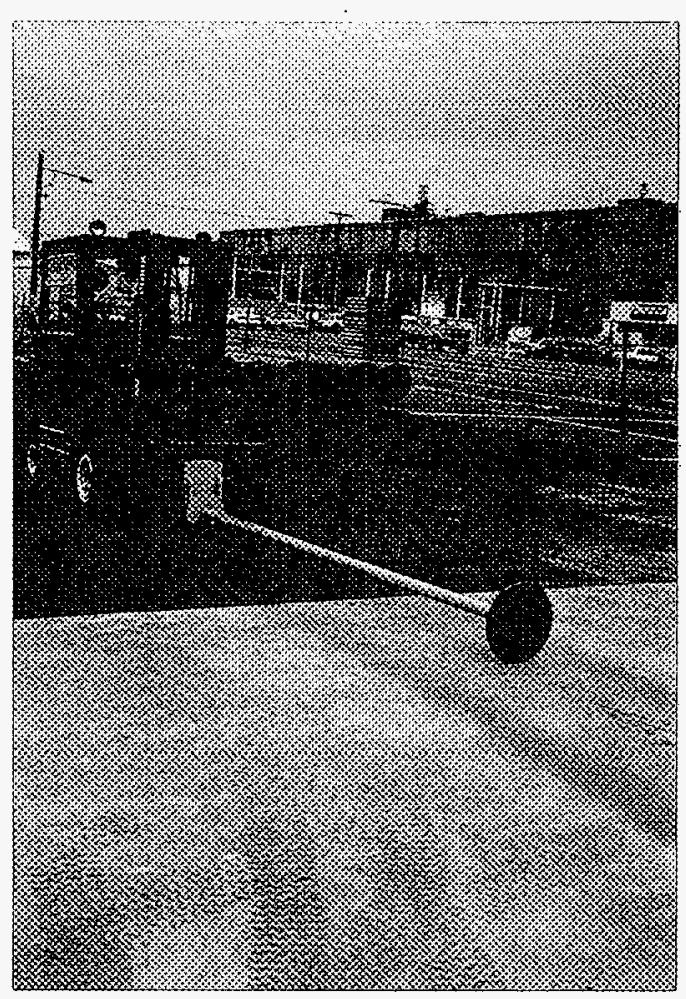

FIGURE 3-4 Drum Ram 


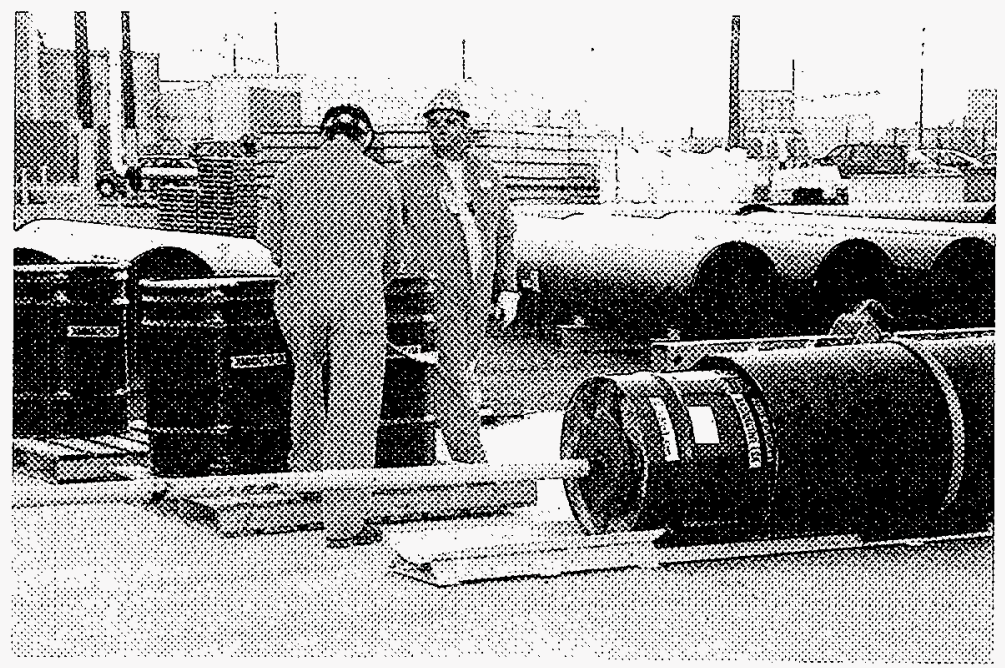

FIGURE 3-5 ARROW-PAK Loading 


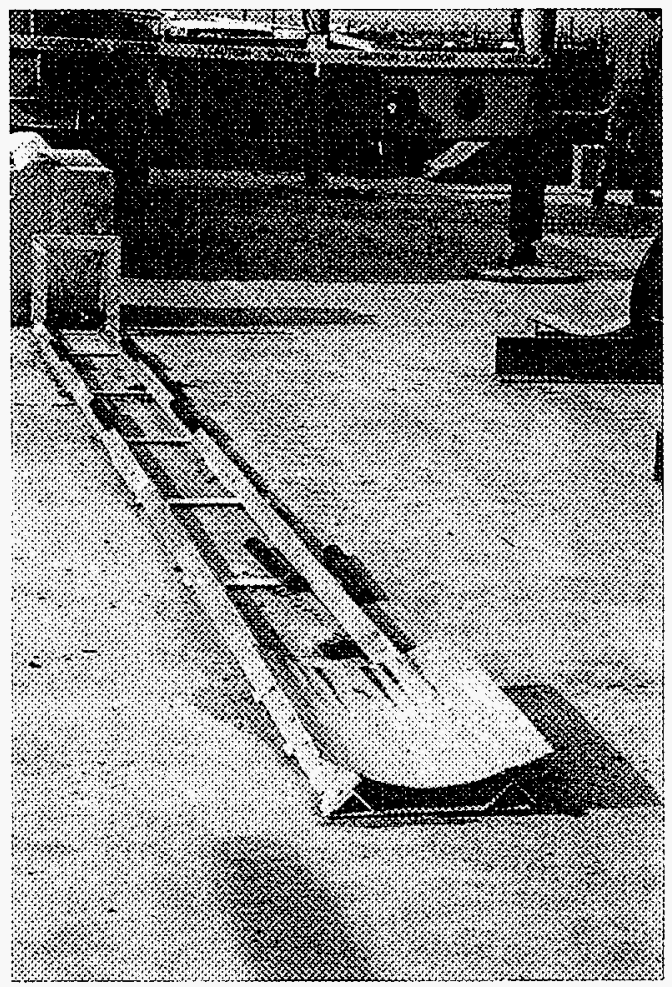

FIGURE 3-6 ARROW-PAK Loading Rack 


\subsection{Material Requirements}

The principal material used for the Macroencapsulation Treatment Demonstration was polyethylene pipe and end caps manufactured from previously DOE-tested and qualified polymer Marlex resin. The physical properties of this material are summarized in Section 4.1. The engineering specifications are described in Section 4.2. The benefits of this material, when used in the ARROW-PAK treatment and final disposal application, are included in Section 4.4.

\subsection{Personnel Requirements}

Arrow Construction's patented macroencapsulation process is streamlined with minimum personnel requirements. It requires 3 qualified key personnel and about 3-4 support personnel who have received the training outlined in Section 3.2.4. The qualifications requirements of these individuals are listed below.

\subsubsection{Key Personnel}

Project Director (trained in accordance with Section 3.2.4) is responsible for the overall planning and coordination of the project, and is thoroughly familiar with all facets of the patented fusion process.

Fusion Specialist (trained in accordance with Section 3.2.4) is responsible for the fusion process and ARROW-PAK fusion equipment operations, with experience in successfully completing hundreds of fusion welds using the Marlex resin material (or at least 3-4 years of experience in conducting HDPE fusion welds).

Quality Assurance/Health and Safety Officer (trained in accordance with Section 3.2.4) is responsible for: 1) advising the Project Director on quality-related issues and necessary corrective actions to remedy non-conforming situations up to and including the cessation of work; 2) implements procedures and oversees and evaluates project activities in accordance with the Quality Assurance Program Plan; and 3) ensuring project activities are conducted in accordance with all applicable health and safety policies and procedures. The Health and Safety Officer conducts all required health and safety meetings, is thoroughly familiar with the appropriate job hazard analyses, and has authority to halt on-site work based on safety hazards when and if necessary. The QAO/HSO should have at least 5 years of experience in waste management or environmental remediation.

\subsubsection{Support Personnel}

Master Mechanic (trained in accordance with Section 3.2.4) provides setup and testing of equipment before and during on-site operations; has material handling expertise, and is responsible for equipment maintenance.

Materials Technical Advisor (trained in accordance with Section 3.2.4) advises the Project Director on matters concerning the manufacture, procurement, storage, and applications of the HDPE during the ARROW-PAK macroencapsulation process. 
Loading Foreman (trained in accordance with Section 3.2.4) is responsible for feedstock loading and handling of the ARROW-PAK Treatment Units. The Loading Foreman is directly responsible for supervising the actions of equipment operators assigned to the project.

\subsection{Waste Management Requirements}

The waste generated by Arrow Construction's macroencapsulation process is minimal. It is restricted primarily to HDPE shavings, rags. and miscellaneous trash and debris. The HDPE shavings generated by the facing function of the ARROW-PAK Fusion Unit are required to be collected, secured in trash bags, and surveyed by the Health Physics Technician for contamination levels before disposal/recycling.

\section{ARROW-PAK TECHNOLOGY}

This section describes Arrow Construction's proprietary and patented alternative macroencapsulation treatment technology, known as "ARROW-PAK". It summarizes the ARROW-PAK fabrication process and reviews the technology's benefits when used to immobilize low-level radioactive or mixed waste. ARROW-PAK was demonstrated for tullscale production use in the Mixed Waste Treatment Demonstration Project at the T-Plant complex, DOE Hanford Site from September 2-11, 1997. The material from which ARROWPAK is fabricated was previously evaluated and qualified by researchers at the Idaho National Engineering Laboratory, EG\&G Idaho, Inc., following accelerated testing for leak tightness, structural strength, and environmental resistance. The scope and conclusions of DOE's tests are included in a report entitled, Demonstration and Evaluation of Arrow Construction's ARROW$P A K$ as an Alternative Macro and Improved Container for Mixed Waste Storage and Disposal. Idaho National Engineering Laboratory, April 1994 (DOE Contract No. DE-AC07-761D01570).

\subsection{Technology Description}

ARROW-PAK is a patented monolithic High Density Polyethylene (HDPE) unit manufactured from a DOE-tested and qualified polymer, then heat-fused to provide treatment of low-level and mixed waste for up to 300 years. Following is a brief description of the three elements that define the ARROW-PAK technology, including the ARROW-PAK unit itself, the polymer from which it is manufactured, and the thermal HDPE fusion process that produces the monolithic treatment unit for the end-user.

ARROW-PAK Unit: A multi-purpose unit which has been qualified for macroencapsulation treatment and final disposal, certified as a High Integrity Container (HIC), and satisfies DOT 7A Package requirements for transportation and disposal. The unit is manufactured from a DOE test-qualified extra-high molecular weight HDPE pipe-grade polymer resin. It has the correct balance of physical and chemical properties to provide long-term waste treatment and immobilization, for up to 300 years, as confirmed by DOE's previous accelerated testing. Three components of HDPE material were used to fabricate each ARROW-PAK unit used during the Treatment Demonstration: one extra-thick ( 0.923 inch wall thickness) Central Section pipe closed by two 1.375 inch thick round end caps that are joined to the Central Section by heat 
fusion. The ARROW-PAK unit is available in several different lengths, diameters, thicknesses. and configurations depending on the treatment or final disposal application desired (i.e., lead. debris, boxes, or long-length material).

Polymer: The current market offers many different types and grades of HDPE. However. ARROW-PAK's extra-high molecular weight HDPE Marlex resin is the only one commercially available that has been DOE-tested and qualified against 40 CFR performance criteria to meet the definition and requirements of HICs, DOT 7A Packaging. and macroencapsulation treatment. This Marlex resin has been specifically fabricated by Phillips Driscopipe to have the highest concentration of hydrogen atoms among plastics. The high concentration of hydrogen atoms is an effective neutron moderator that is actually strengthened by irradiation through crosslinking of the HDPE's molecular structure. During their evaluation of ARROW-PAK at INEL, DOE/EG\&G Idaho researchers concluded that the strength and dimensional properties of the thermally-fused HDPE Marlex resin are unaffected by gamma irradiation to a total dosage of over $0.7 \mathrm{Mrad}$. This dosage is equivalent to the maximum expected dosage for contact-handled waste over a HDPE lifetime of greater than 300 years. Additionally, this HDPE Marlex resin was designed for ultra-violet (UV) radiation resistance, and tested as a part of the NNEL evaluation. The ARROW-PAK was found to be resistant to structural degradation from UV radiation for a period of 100 to 300 years.

Thermal HDPE Fusion: ARROW-PAK's patented fabrication process is unique because the thermal HDPE fusion encompasses the entire cross-section of pre-planed pipe (i.e.. Central Section) and endcaps, not just the inner and outer surfaces of the ARROW-PAK unit. The fusion process thermally melts the HDPE's semi-crystalline molecular structure. Upon cooling, the polymer chains in both the pipe and endcap physically co-mingle, co-entangle, and resolidify into a homogeneous and monolithic unit. Previous DOE testing has shown that the joint created by this process is visually indistinguishable from the original components and completely leak-tight. The joint material is as strong as the parent material and is mechanically stronger than the pipe to which it is joined due to increased wall area. As stated above, this joint is strengthened by irradiation through crosslinking.

This form of fusion, called "butt fusion", has proven the most reliable thermal fusion method for over 35 years in natural gas pipeline and water/wastewater infrastructure construction applications. Millions of butt-fused joints are in service today. ARROW-PAK is unique because it uses a butt fusion weld in the fabrication process. Most commercially available HDPE packages that have been identified as an improved container for interim storage/disposal of mixed wastes involve an interlocking mechanism (i.e., a screw-top cap), an interlocking fusion on the outer surface of the seam, or a combination of these approaches.

\subsection{ARROW-PAK Engineering Specifications}

The engineering specifications for the standard 28-inch ARROW-PAK Unit, and the custommade 30-inch ARROW-PAK Unit designed for the Macroencapsulation Treatment Demonstration, are shown in Table 4-1. The standard unit is designed for encapsulating standard DOT-approved 55-gallon drums with a typical outside diameter of 24 inches. Arrow Construction, Inc. manufactured the 30-inch ARROW-PAK Unit in response to Waste 
Management Federal Services of Hanford, Inc.'s requirements for the macroencapsulation of custom-made 70-gallon overpack feedstock drums. each with an outside diameter of 27 inches.

\section{Table 4-1. ARROW-PAK Engineering Specifications for Standard 28-Inch Inch Units}

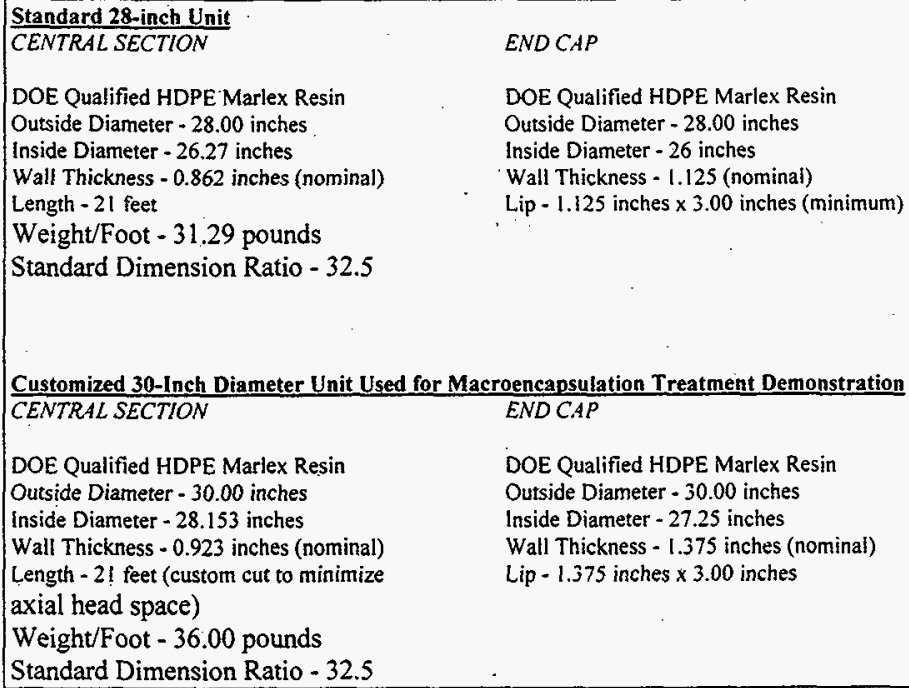

Customized 30-Inch Diameter Unit Used for Macroencapsulation Treatment Demonstration

CENTRAL SECTION END CAP

DOE Qualified HDPE Marlex Resin

Outside Diameter -30.00 inches

inside Diameter -28.153 inches

Wall Thickness -0.923 inches (nominal)

Length -2 ! feet (custom cut to minimize

axial head space)

Weight/Foot $-36: 00$ pounds

Standard Dimension Ratio - 32.5

DOE Qualified HDPE Marlex Resin

Outside Diameter -30.00 inches

Inside Diameter - 27.25 inches

Wall Thickness -1.375 inches (nominai)

Lip -1.375 inches $\times 3.00$ inches

\subsection{ARROW-PAK Fabrication}

The 30-inch ARROW-PAK for the Macroencapsulation Treatment Demonstration at the DOE Hanford Site was fabricated using the patented fusion process described in Section 4.1. Arrow Construction, Inc., employed an ARROW-PAK Fusion Unit which can perform fusions on outside pipe diameters of 12 to 36 inches. The ARROW-PAK Fusion Unit is mobile, selfcontained, and can be operated at remote locations. A separate stand-alone diesel-powered generator provides the power to operate the electrically-driven hydraulic functions on the fusion unit. The generator provides $230 \mathrm{~V}, 60$ cycle, 3-phase power with a rating of $30 \mathrm{kVA}$.

The ARROW-PAK Fusion Unit is first positioned in a level area free from physical and chemical hazards and is secured in place by setting the brake provided on the left rear wheel. The generator unit is positioned near the fusion unit at a distance that will allow adequate working space around the fusion unit, with safety precautions taken regarding equipment maneuverability 
and trip/fall hazards. Once the fusion unit is positioned appropriately, it is lifted off its rubber tire base with its frame support blocked to provide strength and rigidity of support during fusion operations. It is then aligned with the pipe support rollers that bear the ARROW-PAK loads to the left side of the "controls portion" (i.e., the left side) of the fusion unit.

Following is a brief summary of the five major steps in the ARROW-PAK fabrication process. including:

- Alignment and Calibration

- Loading

- Facing

- Heating

- Fusing

Alignment and Calibration: Following pre-operational checks by the Fusion Specialist, the heater is plugged in and allowed to rise to the required fusion temperature of $400-425^{\circ} \mathrm{F}$. While the heater plate is coming up to operational temperature, the Fusion Specialist makes the appropriate adjustments on the hydraulic pressure regulators used to control the facing pressure, heating pressure, and fusing pressure. It takes approximately 20 to 25 minutes for the heater plate to reach operational temperature. The temperature is displayed by a dial thermometer located on the perimeter of the heater plate. The operational temperature is additionally recorded at four equal intervals $(90,180,270$, and 360 degrees) on both sides of the heater plate using a calibrated hand-held pyrometer. This pyrometer check is witnessed and documented by the Quality Assurance Officer.

Loading: Empty and loaded ARROW-PAK units are easily loaded onto the pipe support rollers adjacent to the ARROW-PAK Fusion Unit using crane and rigging equipment (including a spreader bar with synthetic web slings) handled and supervised by qualified personnel. The ARROW-PAK sleeve is positioned in the fusion unit and secured in place by the double clamshell clamps, located on the left side of the operator controls. The majority of the ARROWPAK unit is supported by the three pipe support rollers with the fusion end of the ARROW-PAK supported by the fusion unit itself (see Figure 4-1). The endcap is wiped clean of dust and debris and placed in the endcap fixture/single clamshell clamp located immediately to the right of the operator controls on the fusion unit. The Fusion Specialist secures the endcap on the endcap fixture assembly using six manual screw jacks while visually ensuring proper alignment (i.e.. 360-degree contact) with the adjacent ARROW-PAK sleeve.

Facing: Facing (or planing) of the two surfaces to be joined is accomplished by hydraulically positioning the facer plate (or "facer") between the ARROW-PAK sleeve and the end cap. The Fusion Specialist applies slight pressure ( 80 to 120 psig) on both sides of the facer as it is rotated at approximately $30 \mathrm{rpm}$. During its rotation, the facer plate effectively planes both the endcap and ARROW-PAK sleeve into a clean and parallel surface that is ready for fusing. After the two mating surfaces have been sufficiently planed, the facer is then rotated out of position. 
Alignment of the two surfaces is checked and, if necessary, refaced until proper alignment is achieved. The facing process is illustrated in Figure 4-2.

Heating: Once the endcap and pipe surfaces have been properly planed and the heating plate has reached its proper operating temperature, as recorded during the 4-point check on both of its sides (see above), the facer is rotated out of position and is replaced by the heater plate. The surfaces to be fused are then hydraulically positioned against the heater plate. Before the heater plate is brought into contact with the HDPE material, a heat insulator, approximately 34 inches in diameter and 3/8-inch thick, is inserted between the heater plate and the Center Section (see Figure 4-3). The heat insulator, in effect, compensates for the thicker mating surface of the endcap by allowing the heater plate to bring it to proper melt without over-melting the mating surface of the ARROW-PAK sleeve which has a smaller diameter and wall thickness (see Table 4-1). Once the endcap expresses an acceptable melt bead around its circumference (approximately 3/16-inch wide), the heat insulator is removed, allowing the sleeve and the endcap to be heated simultaneously by the heater plate (see Figure 4-4). After a uniform bead of heated material measuring 3/16-inch to $1 / 4$-inch thick has formed around the entire circumference of both sleeve and endcap, the hydraulic pressure is released and heater plate removed.

Fusing: After removing the heater plate, the two heated surfaces are compressed together under sustained hydraulic pressure of 440 psi (nominal) and allowed to cool for a period of approximately 35 to 45 minutes. This final step of the fusion process ensures a single monolithic bond of fused HDPE material and produces a leak-free joint stronger than the sleeve and endcap themselves in both tension and hydrostatic loading. Upon compression, overflow beads are formed as shown in Figure 4-5. 


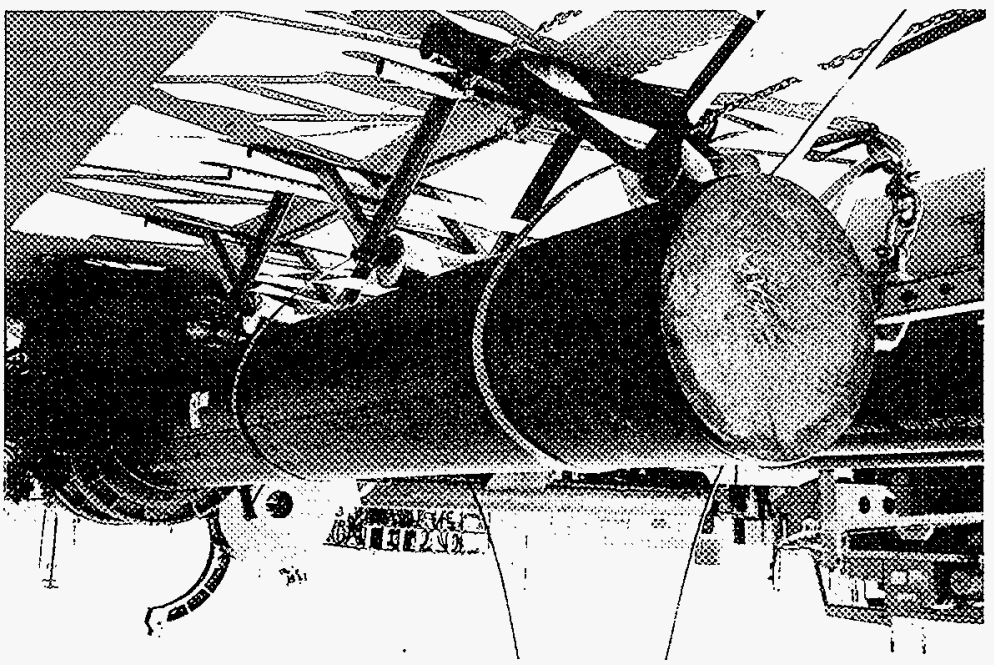




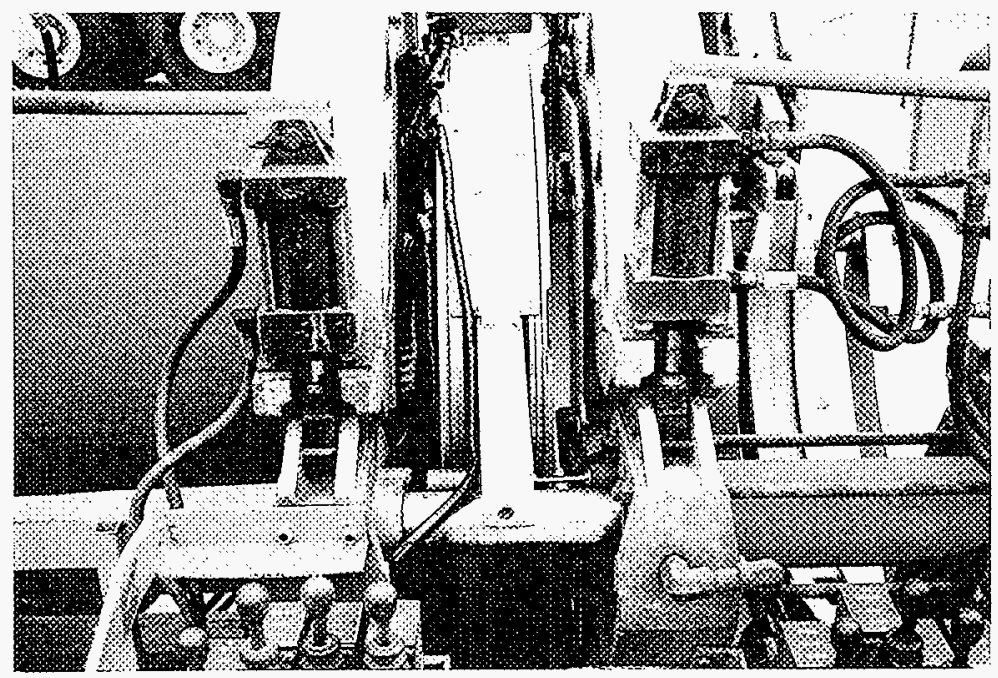

FIGURE 4-2 ARROW-PAK Sleeve Facing 


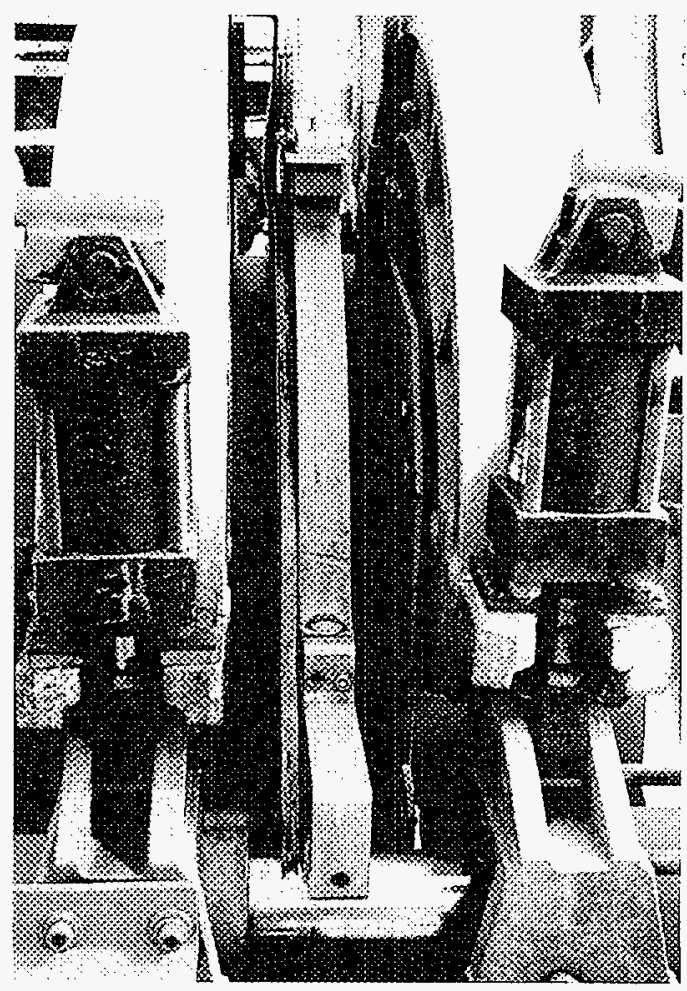

\section{FIGURE 4-3 Heating Endcap}




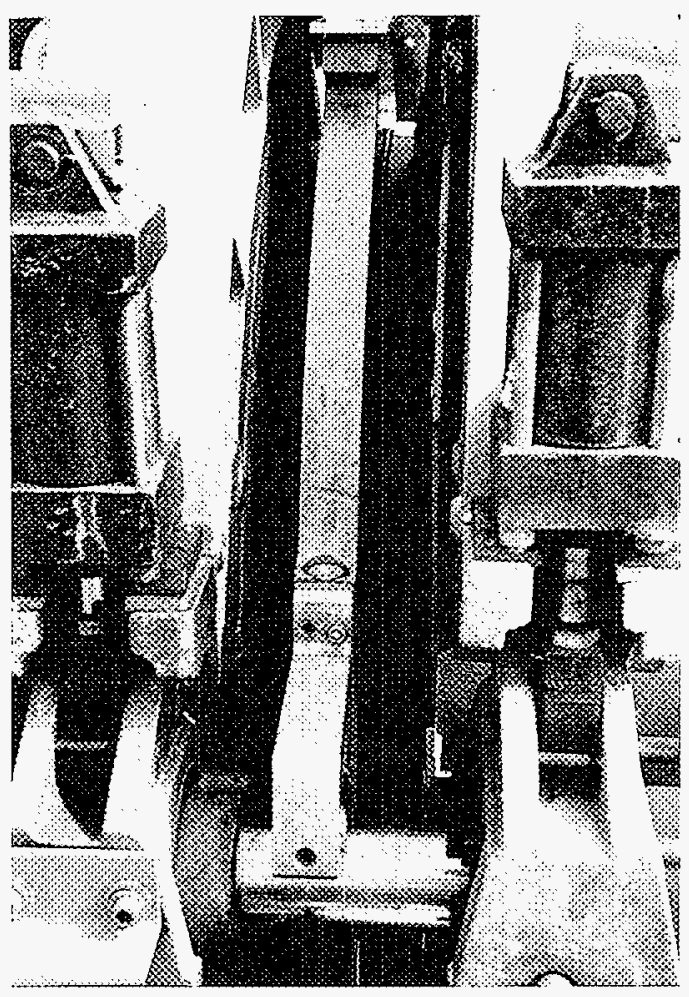

FIGURE 4-4 Heating Endcap and Sleeve 
$6 z-b$

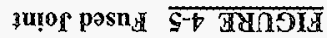

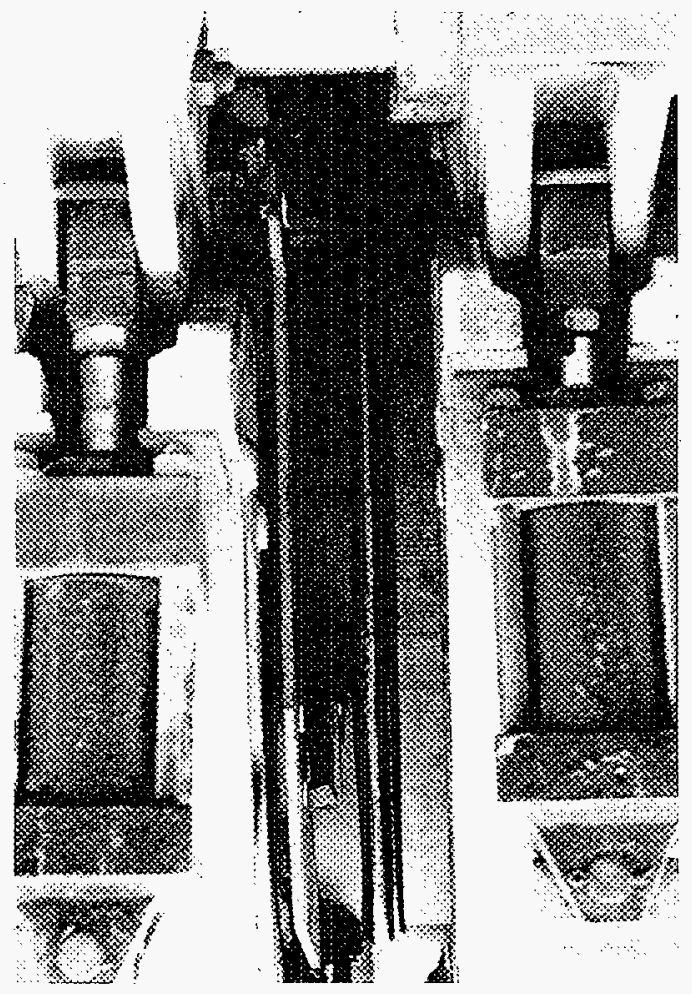

L661 +2 taqo100 - hoday puij. 
The fused endcap and sleeve are then removed from the ARROW-PAK Fusion Unit by releasing the screw jacks securing the clamshell clamps and employing the designated crane and rigging removal procedure. The ARROW-PAK macroencapsulation unit, now fused at one end, is filled with the appropriate waste material and loaded back into the fusion unit via the designated crane and rigging procedure for full waste loads. The preceding steps are then repeated, fusing the second endcap to the open end of the filled ARROW-PAK. This completes the ARROW-PAK fabrication process. For this Demonstration Project, the first endcap was installed off-site prior to shipment to Hanford to reduce the time required for field operations.

\subsection{ARROW-PAK Benefits}

The Department of Energy's interest in undertaking the ARROW-PAK Macroencapsulation Treatment Demonstration at the DOE Hanford Site was based on its determination in 1996 that ARROW-PAK offered a number of immediate and practical benefits, including the following:

- Employs conventional industrial techniques using DOE-tested and -qualified materials;

- Minimizes human exposure;

- Is a cost-effective pre-tested and pre-qualified macroencapsulation technology;

- Uses mobile systems that can be deployed immediately at any DOE site;

- Can be custom fabricated in a range of diameters and virtually any length;

- Can be field cut and re-fused if retrieval of individual drums within a sleeve becomes necessary;

- ARROW-PAK has achieved the following regulatory compliance status:

- Satisfies US EPA's definition of macroencapsulation per 40 CFR 268.42;

- Classified as Best Demonstrated Available Technology for treatment of lead;

- Is an accepted means of meeting US EPA's Alternate Debris Treatment Standards per 40 CFR 268.45;

- Meets 40 CFR 265.315 when used in conjunction with a volume reduction process;

- Should meet DOT Spec7A Type A Packaging per 49 CFR 173; and

- Satisfies requirements of WAC 173-303 for a macroencapsulation technology.

ARROW-PAK's unique physical characteristics deliver a number of additional benefits to the user of this technology as described below:

Leak Tight: ARROW-PAK's demonstrated leak tightness eliminates any concerns associated with leachability of its contents. 
- Previous DOE/INEL testing has certified ARROW-PAK as leak tight to a detection limit at or below $1.27 \times 10-7$ mbar $(1.9 \times 10-9$ psig)

- Leak tightness of the thermally fused area is unaffected by the diameter or thickness of HDPE material

- ARROW-PAK remains leak tight following incidental bumping or impact and drops up to a height of $8 \mathrm{ft}$.

Radiological Resistance: ARROW-PAR can safely and durably immobilize low-level radioactive/mixed waste for a period of up to 300 years.

Strength and dimensional properties of the thermally fused Marlex resin are unaffected by UV and gamma irradiation to a total dosage of over $0.7 \mathrm{Mrad}$, as documented by DOE/TNEL accelerated testing. This dosage is equivalent to the maximum expected for contact-handled waste over a HDPE lifetime of greater than 300 years

Chemical Resistance: ARROW-PAK can be applied to most hazardous/mixed waste streams within the DOE complex.

- Immersion tests in over 600 chemicals, mixtures, and compounds have proven ARROW-PAK inherently resistant to most chemicals

- Most acids, bases, and other chemicals can be immobilized by ARROW-PAK

- Strong oxidizing agents (i.e., fuming sulfuric acid) can be handled through dilution

- Biodegradation is virtually nonexistent

- Liquid hydrocarbons will not degrade the HDPE material

- The strength and dimensional properties of the thermally fused material are also unaffected by 51- to 56-day exposures to simulated acid rain solutions of low pH (per DOE's accelerated testing)

- All dimensional, tensile, and tear resistance properties were within the acceptance threshold established by the National Sanitation Foundation for polymeric liners

\section{Life Expectanicy: ARROW-PAK provides a permanent treatment, immobilization and final disposal solution.}

- Conservatively estimated to be $>100$ years based on hydrostatic testing data

- Estimated to be 300 years for low-level radioactive waste based on accelerated testing conducted by DOE/INEL

- Buried ARROW-PAK is structurally stable in compacted soils for equal longevity

Light Weight: ARROW-PAK is easy to handle and realizes substantial cost savings by reduced manpower and equipment requirements.

- ARROW-PAK weighs only $31.29 \mathrm{lbs} /$ foot or $657 \mathrm{lbs} /$ unit (28-inch O.D.) and 36.00 $\mathrm{lbs} /$ foot or $756 \mathrm{lbs} / \mathrm{unit}$ ( 30 -inch O.D.) 
- Floats in water

- $70-90 \%$ lighter than concrete, cast iron, or steel

- Requires only one forklift and one crane for macroencapsulation operations

Easy to Load: Encapsulation of metal drums is quick and easy with low insertion force.

- Extremely smooth inside surface

- High abrasion resistance

Strength: ARROW-PAK will flex or elongate and stress relieve itself rather than rupture.

- Ductile, not brittle; strain tolerant

- Flexes, bends, and absorbs impact loads over a temperature range of $-180^{\circ}$ to $+260^{\circ} \mathrm{F}$

- Absorbs pressures, vibrations, and stresses without permanent damage and with no adverse effect on long-term service life; DOE/INEL testing demonstrated that ARROW-PAKs are impervious to failure under nearly all potential accident conditions that may be encountered during handling

- Expansive force of waste freezing inside of ARROW-PAK will not damage it

Weatherability: ARROW-PAK can be safely stored outside in most climates for periods of over 100 years without danger of adverse weather effects.

- Contains $2.5 \%$ finely divided carbon black

- Protected against degradation caused by ultra-violet rays when exposed to direct sunlight

- Not necessary to use other light stabilizers or weather absorbers

Temperature Stability: ARROW-PAK has proven durable at normal operating temperatures. Engineering control measures can mitigate against fire damage.

- ARROW-PAK's central section (sleeve) and endcap are heat-fused at a temperature range of $390-425^{\circ} \mathrm{F}$ (nominal $400^{\circ} \mathrm{F}$ )

- ARROW-PAK polymer will start to soften and melt at about $260^{\circ} \mathrm{F}$

- HDPE Marlex resin has been tested for thousands of hours at elevated temperatures of $140^{\circ} \mathrm{F}$ and $176^{\circ} \mathrm{F}$ without thermal degradation

- Exposure to normal changes in temperature does not cause material degradation

- ARROW-PAK polymer is stabilized to protect against degradation at melt temperatures

- ARROW-PAK polymer has very high heat capacity and is difficult to ignite (except under forced combustion) 


\section{PERFORMANCE DATA}

\subsection{Compaction}

Compaction of the mixed waste debris was jdentified as a necessity to meet requirements of the Washington Administrative Code 173-303 for volume reduction. During the planning stages of the compaction treatability study, it was estimated that ATG Richland would be able to accomplish at least a 4 to 1 compaction ratio on a feed stream of 1000 drums. It was therefore estimated that approximately 250,55 -gallon drum volumes would be generated at the end of the study. Based on these assumptions, and an allowance for secondary waste generation. it was determined that approximately 41 ARROW-PAK Macroencapsulation Treatment Units would be necessary to treat the residuals of the ATG compaction treatability study.

ATG Richland operates a 1,500 ton supercompactor designed to reduce materials to near ideal density. The compaction was carried out at the ATG Richland facility during four treatability studies as defined in WAC 173-303. ATG Richland received 717, 55-gallon drums and 163, 85gallon drums that were supercompacted at their facility. The actual feed stream for the compaction treatability study therefore constituted 880 , 55-gallon drums, 120 drums less than were initially planned for.

All 880 drums were entered into the ATG Richland facilities tracking system. The 163, 85 gallon drums had the 55-gallon drums, liners and absorbent removed. 162 of the 85-gallon drums were then declared empty according to the guidelines established in 40 CFR and were returned to Hanford for re-use. The liners and absorbent removed from the 85 -gallon drums were collected and placed in one 85-gallon drum and two B-25 boxes. Banding used to secure all of the drums during shipment from Hanford was also added to the two B-25 boxes mentioned above. Each B-25 box measures 4 feet, by 4 feet, by 6 feet and contains a total of 96 cubic feet of internal volume. There was one additional B-25 box generated during the compaction process that contains all of the filters used during the mixed waste debris compaction treatability study. This B-25 box is approximately $70 \%$ full. In addition to the above mentioned waste, a 55 -gallon drum approximately $70 \%$ full of liquid waste was also generated during the compaction treatability study: The above information identifies 275.7085 cubic feet of waste that was generated during the compaction process. Based on the above information and the assumptions of a 55-gallon drum containing 7.3520 cubic feet of waste and an 85-gallon drum containing 11.3621 cubic feet of waste, Table 5.1.1 and 5.1.2 were developed as summaries that identify container, volume, overall performance and compaction ratios performed by the ATG Richland supercompactor.

The 163, 55-gallon drums removed from the 85-gallon overpacks and the 717 additional 55gallon drums were all sent through the supercompaction process at ATG Richland. The resulting 880 , 55-gallon drum pucks were loaded into modified 70-gallon (9.6 cubic foot) overpacks and returned to the Hanford site for treatment in the ARROWPAK Macroencapsulation Treatment Units. There were a total of $149,9.6$ cubic foot overpacks returned to Hanford for treatment in the ARROW-PAK Macroencapsulation Treatment Units. 
TABLE 5.1.1 General Container And Compaction

Process Waste Generation Information

\begin{tabular}{|lll|}
\hline Container & $\begin{array}{l}\text { Volume } \\
\text { cu. ft. }\end{array}$ & $\begin{array}{l}\text { Waste } \\
\text { Generated } \\
\text { (cu. ft.) }\end{array}$ \\
\hline $55 \mathrm{gal}$ & 7.3520 & 5.1464 \\
$85 \mathrm{gal}$ & 11.3621 & 11.3621 \\
$9-6$ & 9.6000 & 0.0000 \\
$\mathrm{~B}-25$ & 96.0000 & 259.2000 \\
\hline Total & & 275.7085 \\
\hline
\end{tabular}

TABLE 5.1.2 ATG Richland Mixed Waste Debris Compaction Performance Data

\begin{tabular}{|c|c|c|c|c|c|c|c|c|}
\hline $\begin{array}{l}\text { Treatability } \\
\text { Study Number }\end{array}$ & $\begin{array}{l}\text { Treatability } \\
\text { Study } \\
\text { Foed }\end{array}$ & $\begin{array}{l}\text { Treatability } \\
\text { Study Foed } \\
\text { Volume to } \\
\text { Compactor } \\
\text { (cu. Ft) }\end{array}$ & $\begin{array}{l}\text { Treatability } \\
\text { Study } \\
\text { Output (9.6 } \\
\text { cu. th. } \\
\text { overpacks) }\end{array}$ & $\begin{array}{l}\text { Volume After } \\
\text { Compaction } \\
\text { (cu. ft) }\end{array}$ & $\begin{array}{l}\text { Recycle } \\
\text { Volume } \\
\text { Reduction } \\
\text { (cu. ft.) }\end{array}$ & $\begin{array}{l}\text { Total Volume } \\
\text { Reduction } \\
\text { Ratio (cu. ft.) }\end{array}$ & $\begin{array}{l}\text { Compaction Volume } \\
\text { Reduction Ratio (foed } \\
\text { containers/ output } \\
\text { contaniners volume) }\end{array}$ & $\begin{array}{c}\text { Total Reduction } \\
\text { Ratio }\end{array}$ \\
\hline 1 & $\begin{array}{c}163 \\
85 \text { gal }\end{array}$ & 1198.3692 & 30.0000 & 288.0000 & 642.2938 & 1552.6630 & 4.1610 & 6.3912 \\
\hline 2 & $\begin{array}{c}240 \\
55 \mathrm{gal}\end{array}$ & 1764.4700 & 38.0000 & 364.8000 & 0.0000 & 1399.6700 & 4.8368 & 4.8368 \\
\hline 3 & $\begin{array}{c}240 \\
55 \mathrm{gal}\end{array}$ & 1764.4700 & 40.0000 & 384.0000 & 0.0000 & 1380.4700 & 4.5950 & 4.5950. \\
\hline 4 & $\begin{array}{c}237 \\
55 \text { gal }\end{array}$ & 1742.4141 & 41.0000 & 393.6000 & 0.0000 & 1348.8141 & 4.4269 & 4.4269 \\
\hline $\begin{array}{l}\text { Generated } \\
\text { Waste }\end{array}$ & & & & & & -275.7085 & & \\
\hline Total & 880 & 6469.7233 & 149.0000 & 1430.4000 & 642.2938 & 5405.9086 & & 4.7793 \\
\hline
\end{tabular}

The above tables indicate that ATG Richland was able to achieve an overall volume reduction ratio of roughly 4.8 to 1 . This represents a $60 \%$ better compaction ratio than originally speculated. The increased compaction ratio combined with 120 fewer 55 -gallon drums to treat resulted in Hanford purchasing approximately 19 ARROW-PAK Macroencapsulation Treatment Units that were not utilized by this project. 


\subsection{Macroencapsulation}

The Macroencapsulation Treatment Demonstration at the DOE Hanford Site has strategic value to the Department of Energy given the volume of future mixed waste streams at the Hanford Site and other sites throughout the DOE complex, and the DOE's preference for managing mixed waste debris under the alternate debris treatment standards of 40 CFR 268.45. The focus of the demonstration was Arrow Construction's proprietary and patented low level/mixed waste treatment technology, ARROW-PAK, that had successfully passed DOE/INEL's earlier series of tests (see Section 4.0). This treatment demonstration at Hanford was funded by the DOE's EM30 and EM-50 "Mixed Waste Focus Group" with the following three purposes in mind:

- To address technical and regulatory problems associated with bringing a pilot-scale operation to a full production-scale operation;

- To validate on a full-scale under actual field conditions the conclusions of DOE/INEL's previous demonstration and evaluation of ARROW-PAK which involved the use of surrogate (inert) waste under.simulated field conditions; and

- To generate performance and cost data that can be used by other sites within the DOE complex and other federal agencies who may be interested treating and disposing of their low-level/mixed waste under the debris rule of 40 CFR 268.45.

This section summarizes the performance data that were generated during the Macroencapsulation Treatment Demonstration at Hanford and validates the conclusions of DOE/INEL's earlier testing of ARROW-PAK. This project has demonstrated that ARROWPAK is a commercially available technology, manufactured from DOE tested and qualified material, that can provide treatment, long-term storage and/or final disposal of low-level/mixed waste immediately under the "debris rule" of 40 CFR 268.45 .

Cost data generated during this project are summarized in Section 6.0. Regulatory and technical issues associated with full production-scale application of ARROW-PAK are discussed in Section 7.0.

\subsubsection{Performance Summary}

- Waste Management Federal Services of Hanford, Inc. scheduled 880, 55-gallon drums containing low-level tank farm waste debris to be compacted, overpacked and encapsulated in ARROW-PAK during the Macroencapsulation Treatment Demonstration Project. Hanford Radiological Work Permit T-860 allowed for a start date of 25 August, 1997 and an end date of 15 October, 1997. The revised Work Plan scheduled macroencapsulation (i.e., fusion) operations to be completed by 17 September, 1997.

- The 880 feedstock drums were compacted and placed (by others) into 149 steel overpack drums, at an average compaction ratio of 4.8 to 1 , over a period of three weeks during August, 1997. 
- Arrow Construction received 4 days of required training (HGET, T-Plant Orientation, and Radiological Worker Training, Level II) and conducted one-day site setup and coordination with Waste Management Federal Services of Hanford, Inc. Safety, Operations, and Crane \& Rigging personnel during the period 25-29 August, 1997.

- The Crane and Rigging team loaded all of the overpack drums into a total of 22 ARROW-PAKs over a period of four days. Twenty-one of these ARROW-PAKs were standard 21-ft. units, each containing 7 overpack drums, or 42 feedstock drums.. One unit was customized for 2 overpack drums, or 12 feedstock drums.

- Arrow Construction completed fusion of the 22 ARROW-PAK Macroencapsulation Treatment Units under controlled quality procedures and conditions, within 5 working days (4-5, 8-10 September, 1997). It is noted that fusion of the first endcap (i.e., first of two endcaps) on ench of these 22 units was completed off-site, unter the identical quality procedures and conditions, in 6 toorking days (14-19 Nozember, 1996).

- The gross weight of all 22 waste-loaded ARROW-PAK units was $143,215.9$ lbs., or 71.6 short tons. Net weight (i.e., less the weight of the HDPE material) of all 22 units was $125,325.9 \mathrm{lbs}$., or 62.7 short tons.

- The average gross weight of the twenty-one 21-ft. ARROW-PAKs was $6,736 \mathrm{lbs}$. The gross weight of the single customized 2-overpack drum container was $1,761 \mathrm{lbs}$.

- Arrow Construction successfully demonstrated that ARROW-PAK immobilized and, thus, treated all of the mixed waste debris in this project pursuant to the provisions of 40 CFR 268.45 (see Attachment 2).

- Arrow Construction effected treatment of low-level/mixed waste debris at the rate of 12.54 tons/day (approximately 30 overpack drums/day) during this demonstration.

- Arrow Construction completed the last fusion weld at 3:15 p.m. (Pacific) on 9 September, 1997, six working days ahead of schedule.

\subsubsection{Overall Project Schedule}

Planning and preparation for the project began in September, 1996 when Arrow Construction. Inc., with assistance from Boh Bros. Construction Co., Inc. (fusion process) and Ogden Environmental and Energy Services Co., Inc. (environment, safety \& health) prepared the following planning documents pursuant to Arrow Construction's contract requirements under AST Environmental Services: Work Plan, Site-Specific Health and Safety Plan, Quality Assurance Program Plan, and Contingency Plan. These documents were finalized in early December, 1996.

In anticipation of completing macroencapsulation field operations by 31 December, 1996, as then required under Arrow Construction's contract obligations, ASTES and Westinghouse Hanford Company (predecessor to Waste Management Federal Services of Hanford. Inc.) approved Arrow's request to fuse the first endcap on each of 34 empty ARROW-PAK sleeves prior to the 
deployment of equipment and materials to the Hanford Site. This fusion process was conducted by the same qualified personnel (Fusion Specialist and QAO/HSO team), under the supervision of Arrow's Project Director and under the same quality controlled conditions as that conducted during the Mixed Waste Treatment Demonstration at T-Plant. These initial fusion operations were conducted at Boh Bros.' facility in.New Orleans, Louisiana from 14-19 November, 1996. The Hanford treatment demonstration was ultimately postponed until August-September. 1997.

During June-July, 1997, in preparation of the Mixed Waste Treatment Demonstration. Arrow Construction revised its planning documents, as appropriate, to address Waste Management Federal Services of Hanford, Inc.'s revised work schedule and engineering and safety issues associated with material handling equipment. Once these issues were satisfactorily addressed, Arrow Construction mobilized and deployed the equipment for macroencapsulation operations in accordance with the schedule.

Following is summary of scheduled and actual macroencapsulation field activities conducted during the Hanford project.

\begin{tabular}{lcc} 
Activity & Scheduled Date & Actual Date \\
\hline Equipment/materiai onsite (T-Plant) & 25 Aug. 97 & 25 Aug. 97 \\
Set-up macro operations in RBA/RMA & 25 Aug. 97 & 25 Aug. 97 \\
Arrow Team receives training & $26-29$ Aug. 97 & 26.29 Aug. 97 \\
Equipment calibration/Dry run fuse & 2 Sep. 97 & 2 Sep. 97 \\
Macroencapsulation of feedstock & $3-17$ Sep. 97 & $3-10$ Sep. 97 \\
Breakdown area/demobiization & $18-22$ Sep. 97 & $11-15$ Sep. 97
\end{tabular}

\subsubsection{Macroencapsulation Óperations}

This section summarizes the performance data generated during the Mixed Waste Treatment Demonstration. All phases of the macroencapsulation operations were performed in accordance with the procedures described in Section 4.3 (ARROW-PAK Fabrication) and with the requirements described in Sections 3.2 through 3.7, as applicable.

\subsubsection{Mobilization/Set-Up.}

ARROW-PAK's simple and streamlined fabrication process facilitates quick set-up and rapid project completion. As indicated in the schedule above, the RBA/RMA was able to incorporate Arrow's set-up within the scheduled time frame. Actual set-up time for Arrow's equipment was one-half day.

\subsubsection{Overpack Drum Loading.}


The loading of single-fused empty. ARROW-PAKs was conducted intermittently over a period of four days by Crane \& Rigging, as feedstock drums became available onsite. Once the loading process began, it took an average of 8 minutes to load seven modified 70 -gallon steel overpack drums into one empty ARROW-PAK. The first two ARROW-PAKs each required approximately 12 minutes to load. The smooth inside surface of ARROW-PAK, combined with a practically built loading rack and simple ramming device made for a rapid loading process. The process requires a minimal amount of field personnel.

\subsubsection{Fusion}

The fusion process is simple and mobile and can be conducted anywhere under appropriate quality-controlled conditions by trained fusion specialists. The area requirements for ARROWPAK fusion were described in Section 3.3. The equipment and personnel requirements were identified in Sections 3.4 and 3.6, respectively. As explained above, fusion of the ARROW-PAK Macroencapsulation Treatment Units used in this project were conducted in two locations. New Orleans and the Hanford Site, due to scheduling considerations.

Fusion of First Endcap. The single fuse of the first endcap on empty ARROW-PAK sleeves in New Orleans was conducted by Arrow Construction and approved by Ogden Environmental and Energy Services during the period 14-19 November, 1996. The products of this effort (34 singlefused empty ARROW-PAKs) were delivered to T-Plant on 25 August, 1997. Twenty-two of these 34 units were used in the Macroencapsulation Treatment Demonstration. The Fusion Checklist developed and used by Ogden Environmental and Energy Services for each observed weld seal on the first endcap was identical to the checklist used by Ogden to control the quality of the second endcap fusion at T-Plant.

Fusion of Second Endcap. Fusion of 22 "second endcaps" within the RBA/RMA at T-Plant were performed in accordance with the RCRA Inspection Checklists, OSHA Pre-Job Checklists, Fusion Checklists, and where appropriate, Record of Change Forms. In particular, the Fusion Checklists indicate that 100 percent of all waste-loaded ARROW-PAKs were successfully fused pursuant to the quality control procedures followed by the Project Quality Assurance Officer. The fusion process was witnessed by Waste Management Federal Services of Hanford. Inc.'s Quality Representative, and documented by co-signature on each Fusion Checklist.

\subsubsection{Observational Data}

The following observations were made during the Mixed Waste Macroencapsulation Treatment Demonstration:

- Attach sling and remove a fused/treated ARROW-PAK (containing 7 overpack drums, weighing an average of $6,736 \mathrm{lbs}$ ) from the fusion machine to the temporary Treatment Unit storage area and replace with loaded but not fused ARROW-PAK: 5 minutes.

- Align/face/calibrate/check temperature of heating plate for fusion weld: $20-25$ minutes. 
- Heat: approximately 10 minutes, as follows:

- with insulator plate, heating only endcap: 5 minutes

- without insulator plate, heating both endcap/ARROW-PAK sleeve simultaneously: 5 minutes

- Fuse and cool endcap under 440 psi: $35-45$ minutes depending on the time of day ( 35 minutes in the morning, 45 minutes in the afternoon)

- Total Average Time to Complete one ARROW-PAK Fusion Weld : 70 minutes (assuming load is ready on pipe support rollers).

Waste Treatment progress was a function of a variety of factors including:

- Weather

- Availability of Health Physics Technician support

- Availability of Crane \& Rigging Support

- Amount of facing required

Fusion should not be conducted in the open during inclement weather. For this reason, fusion operations were suspended on 3 September, 1997 due to rain. For longer term projects, fusion work should be performed inside a building or under a canopy to minimize weather related downtime. 


\section{COST DATA}

This project was completed as a firm-fixed price contract. Due to the unique nature of this demonstration, there were several cost factors associated with it that would not necessarily be expected on future full-scale production treatment projects. These non-recurring engineering costs have been separated from the costs of field operations. A significant amount of time was spent researching all applicable regulatory requirements and developing the regulatory basis which would allow the project to proceed. Since the project was approved and completed, it is expected that these costs would not be necessary in the future, or would be greatly reduced in magnitude.

Another significant cost was the development of plans and procedures necessary to conduct operations at the Hanford site. These included the Health and Safety Plan, Spill Contingency Plan, Quality Assurance Program Plan, Work Plan, and Operating Procedures. Since these documents have been approved at Hanford, future work at this site would require minimal, if any additional administrative controls. Modification to these plans and procedures for work at other DOE facilities would be expected to require only minor changes to these previously approved documents to conform to site specific requirements.

Since this project was completed as a firm-fixed price contract, certain assumptions had to be made regarding the scope of the field work. Initially, it was assumed that there would be 1,000 mixed waste debris drums treated for this demonstration. The drums were to be supercompacted under a treatability study, and the volume reduction could not be determined with any degree of certainty. For the purposes of establishing the contract price, it was agreed that a compaction ratio of 4 to 1 would be used to bid the project. This resulted in an estimated total of 250 overpack drums to be macroencapsulated. Additionally, it was estimated that secondary waste from the compaction treatability study would result in an additional 30 overpack drums, raising the total number of overpack drums to 280 . Since 7 overpack drums were to be treated with each 21 foot long sleeve, the lump sum contract price included furnishing and fabricating 41 ARROW-PAK treatment units. As stated in earlier sections, the total number of drums was reduced to 880 , and the compaction was much more efficient than estimated, resulting in a compaction ratio of 4.8 to 1 . These two factors combined to reduce the number of overpack drums to be treated to 149 , requiring only 21 full ARROW-PAK sleeves and a partial sleeve. The balance of the material purchased for the project, 19+ ARROW-PAK sleeves and the associated end caps, remain at the Hanford site. It is anticipated that full-scale treatment will be performed on a fixed-unit price basis per drum rather than a lump sum basis, and the cost figures presented here reflect the adjustment for the reduced amount of materials actually required for the project.

The compaction of the 55-gallon drums for this demonstration project was performed off-site at a commercial fixed-base facility. On-site compaction using a mobile supercompactor was considered, and a fixed price quotation was received. Because of the significant up-front costs associated with mobilizing a mobile supercompactor to a site and the small number of drums treated as a part of this demonstration, the overall price was slightly higher for this option than for off-site compaction. However, for larger quantities of drums (i.e.. over 1,000) the total unit cost of on-site compaction compares favorably to off-site compaction. 
To estimate the costs of future work, the firm-fixed unit price quotations that were received for this project will be used. It is assumed that some employee training will be required for each project, and that there will be certain admnistrative and overhead costs associated with performing the work. The cost estimates reflected in this report do not include site support services such as crane and rigging and forklift operations. As can be seen in the following breakdown, the costs are volume dependent, with the unit price per drum decreasing as the number of treated drums increases. Two price scenarios are presented here, one for processing 1,000 55-gallon drums, and the second for processing 2,000 55-gallon drums. These were the only quantities for which price quotations were received. A compaction ratio of 4 to 1 has been used which should be a conservative estimate (although a volume reduction of 4.8 to 1 was achieved on the demonstration project, the drum reduction was 5.9 to 1 , or 880 drums reduced to 149).

CASE 1 - 1,000 55-Gallon Drums

DESCRIPTION

Compaction (On-Site)

Mobiliztion/Demobilization

Permitting and Regulatory Compliance

Empioyee Training

Compaction

Total Compaction

\section{Macroencapsulation}

Mobilization/Demobilization

Permitting and Regulatory Compliance

Employee Training

Macroencapsulation

Total Macroencapsulation

\section{Estimated Project Totals}

Total Compaction

Total Macroencapsulation

Subtotal

$20 \%$ General and Administrative Costs

Total Estimated Cost

\section{OUANTITY UNIT PRICE AMOUNT}

Lump Sum

Lump Sum

$\$ 150,000$

Lump Sum

Lump Sum

50,000

Lump Sum

Lump Sum

30,000

1,000 Drums

$\$ 175.00$

175.000

$\$ 405,000$

Lump Sum

Lump Sum

$\$ 50,000$

Lump Sum

Lump Sum

50,000

Lump Sum

Lump Sum

30,000

250 Drums

$\$ 1,350.00$

337,500

$\$ 467,500$
$\$ 405,000$

467,500

$\$ 872,500$

174,500

$\underline{\$ 1,047,000} \div 1,000$ Drums $=\$ 1047 /$ Drum 
CASE 2 - 2,000 55-Gallon Drums

\section{DESCRIPTION}

Compaction (On-Site)

Mobiliztion/Demobilization

Permitting and Regulatory Compliance

Employee Training

Compaction

Total Compaction

\section{Macroencapsulation}

Mobilization/Demobilization

Permitting and Regulatory Compliance

Employee Training

Macroencapsulation

Total Macroencapsulation

\section{OUANTITY UNIT PRICE AMOUNT}

$\begin{array}{lcr}\text { Lump Sum } & \text { Lump Sum } & \$ 150,000 \\ \text { Lump Sum } & \text { Lump Sum } & 50,000 \\ \text { Lump Sum } & \text { Lump Sum } & 30,000 \\ 2,000 \text { Drums } & \$ 125.00 & \underline{250,000} \\ & & \$ 480,000\end{array}$

Lump Sum

Lump Sum

$\$ 50,000$

Lump Sụm

Lump Sum

50,000

Lump Sum

Lump Sum

30,000

500 Drums

$\$ 1,300.00$

$\underline{650,000}$

$\$ 780,000$

\section{Estimated Project Totals}

Total Compaction

$\$ 480,000$

Total Macroencapsulation

780,000

Subtotal

$\$ 1,260,000$

$20 \%$ General and Administrative Costs

252,000

Total Estimated Cost

$\$ 1,512,000 \div 2,000$ Drums $=\$ \underline{\$ 56 / \text { Drum }}$

Price quotations were recieved for processing up to 2,000 drums. Larger quantities of drums may result in lower unit prices. 


\section{CONCLUSIONS}

Arrow Construction, inc. has successfully completed the field testing of the ARROW-PAK Macroencapsulation Low-Level/Mixed Waste Treatment Unit at T-Plant, DOE Hanford Nuclear Reservation. This project was performed in accordance with all required plans and permits, and the requirements of Waste Management Federal Services of Hanford, Inc.'s project management. health and safety, and quality assurance representatives.

The ARROW-PAK Field Demonstration successfully treated debris mixed waste in accordance with the US EPA Alternate Debris Treatment Standards, 40 CFR 268.45, and the completed ARROW-PAK Treatment Units meet the US EPA Land Disposal Restrictions (LDRs) for permanent disposal.

The ARROW-PAK technology is cost effective, mobile, and available for immediate use throughout the DOE complex for the treatment, storage and/or disposal of mixed waste debris. 


\section{POTENTIAL FOR FULL-SCALE PRODUCTION USE OF ARROW- PAK}

Based on information contained in the Final Waste Management Programmatic Environmental Impact Statement for Managing Treatment, Storage, and Disposal of Radioactive and Hazardous Waste - Summary published by the DOE in May, 1997, there are 37 sites that generate or store low-level mixed waste (LLMW). The DOE will need to manage an estimated 219,000 cubic meters of LLMW over the next 20 years. A significant portion of this LLMW will be classified as debris, and as such, will be amenable to macroencapsulation. A large volume of LLMW debris is currently in storage at DOE facilities throughout the country, and is available for treatment. The ARROW-PAK technology is mobile and does not require the construction of new waste treatment facilities, making it readily available to treat LLMW now. The patented ARROW-PAK system uses materials and equipment that are readily available on a large scale. The fusion process is almost identical to that which has been used for decades on millions of HDPE welds for a variety of applications, leading to industry standards and practices for its use. The ARROW-PAK macroencapsulation technology should gain similar industry acceptance for the treatment of hazardous and LLMW debris.

The 10 largest generators of LLMW within the DOE complex are listed below. These sites would be the leading potential candidates for debris mixed waste treatment.

\begin{tabular}{l|l} 
& \multicolumn{1}{|l}{ MIXED WASTE } \\
SITE & (Cubic Meters) \\
\hline Oak Ridge Reservation (ORR) & 59,000 \\
Hanford Nuclear Reservation & 36,000 \\
Idaho National Engineering and Environmental Laboratory (INEEL) & 35,000 \\
Portsmouth Gaseous Diffusion Plant & 33,000 \\
Rocky Flats Environmental Technology Site (RFETS) & 21,000 \\
Savannah River Site (SRS) & 20,000 \\
Lawrence Livermore National Laboratory (LLNL) & 4,300 \\
Nevada Test Site (NTS) & 3,000 \\
Los Alamos National Laboratory (LANL) & 2,800 \\
Fernald Environmental Management Project (FEMP) & $\mathbf{2 , 6 0 0}$ \\
TOTAL & \\
\hline
\end{tabular}




\section{ATTACHMENT 1}

HANFORD RADIOLOGICAL WORK PERMIT T-860

\section{ATTACHMENT 2}

WASTE MANAGEMENT OF HANFORD, INC. - LETTER OF APPROVAL 


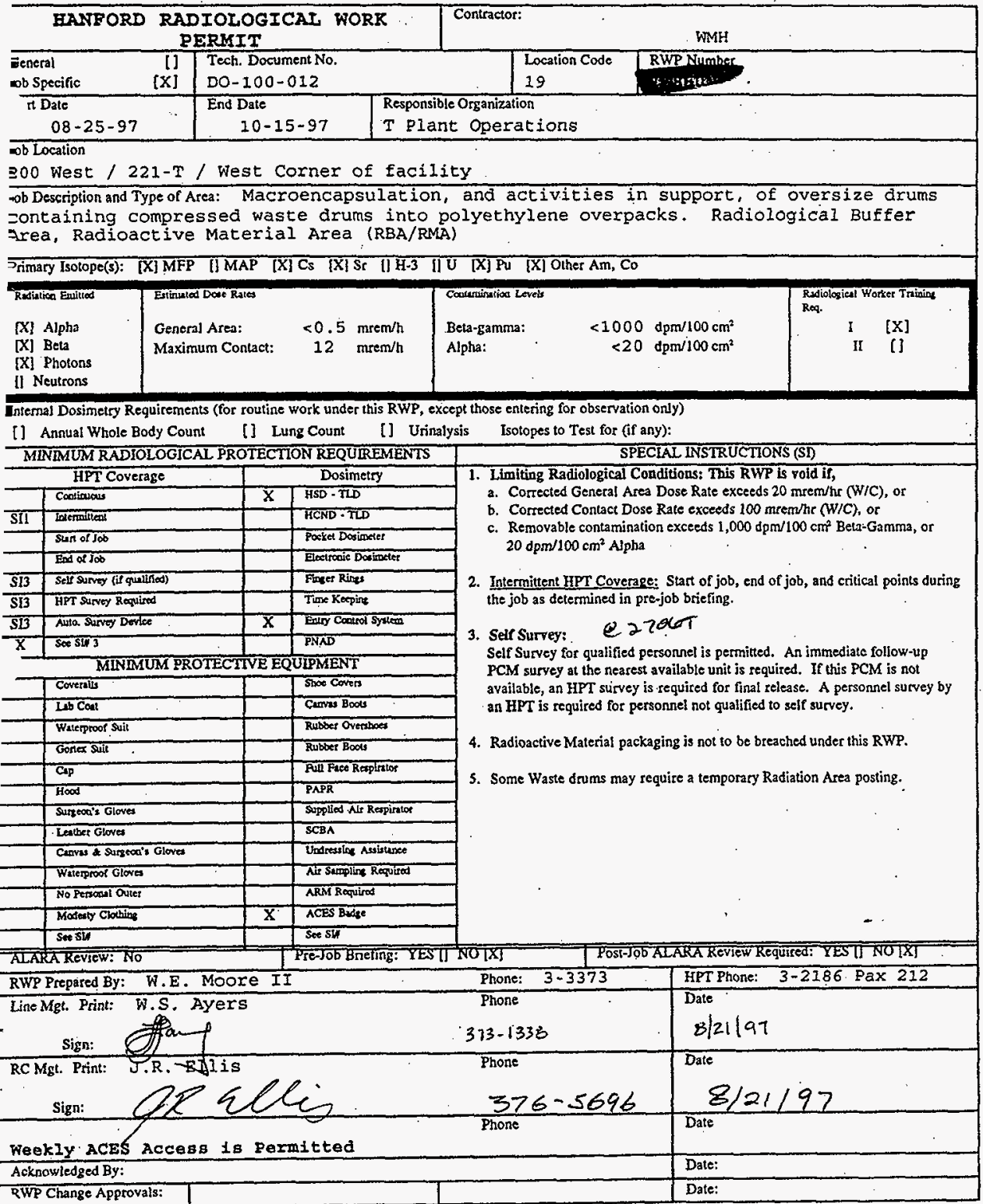




\section{COMPLETION OF ARROW-PAK MIXED WASTE TREATMENT FIELD DEMONSTRATION}

Arrow Construction, Inc., has successfully completed the field testing of its ARROW-PAK Macroencapsulation Low-Level/Mixed Waste Treatment Unit at T-Plant, DOE Hanford Site. This testing was conducted in accordance with Radilogical Work Permit No. T-860, Arrow's Work Plan for the Debris Macroencapsulation Pilot Project, and in close consultation with Waste Management Hanford's project management, safety, and quality representatives.

The ARROW-PAK field demonstration successfully treated debris mixed waste feedstock consisting of 149 70-gallon overpack drums in accordance with the Alternate Debris Treatment Standards, 40 CFR 268.45. The overpack drums were loaded in 21 7-drum ARROW-PAK Macroencapsulation Treatment Units and one 2-drum ARROW-PAK Macroencapsulation Treatment Unit. The field demonstration was intiated on September 2, 1997, and concluded on September 11, 1997.

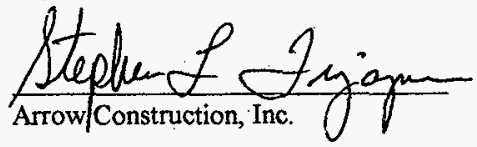

Title: Project Director

Date:

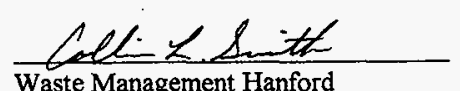

Title: Operatiens Engineer, T P/ant

Date: $9 / 11 / 97$ 


\section{DISTRIBUTION}

\section{Number of copies}

\section{ONSITE}

3

5

8
U. S. Department of Energy-

Richland Operations Office

R. F. Guercia

J. P. Hanson

J. J. Waring

S7-55

$\mathrm{K} 8-50$

S7-55

Fluor Daniel Hanford. Inc.

G. T. Berlin (4)

K9-46

J. W. Golden

N1-26

Lockheed Martin Services, Inc.

Central Files

DPC

Waste Management Federal Services of Hanford. Inc.

T. L. Baker (5)

H6-06

L. Bounini

H6-06

K. L. Hladek

H6-06

L. G. Irons

T3-04 